In cooperation with The University of Arizona

Biological Dimensions of Tern Management-A Case Study of the Least Tern in Sonora, Mexico, and a Comparative Analysis of Reproductive Investment in Terns

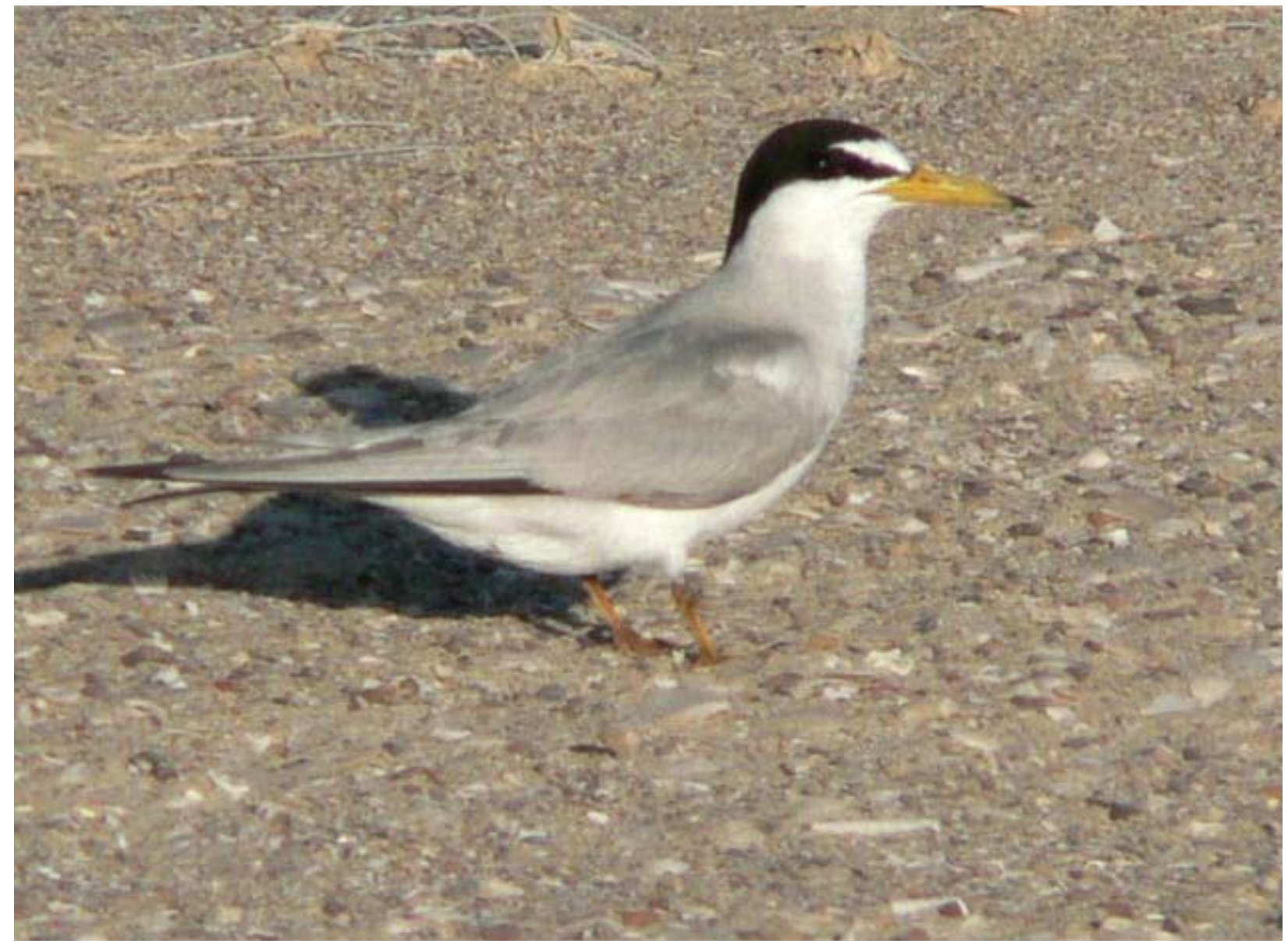

Open-File Report 2010-1085 
Cover: Photograph of a least tern (Sternula antillarum). (Photo by Alyssa Rosemartin.) 
In cooperation with The University of Arizona

\section{Biological Dimensions of Tern Management-A Case Study of the Least Tern in Sonora, Mexico, and a Comparative Analysis of Reproductive Investment in Terns}

By Alyssa Rosemartin and Charles van Riper III

Open-File Report Series 2010-1085

U.S. Department of the Interior

U.S. Geological Survey 


\section{U.S. Department of the Interior \\ KEN SALAZAR, Secretary}

\section{U.S. Geological Survey \\ Marcia K. McNutt, Director}

U.S. Geological Survey, Reston, Virginia 2011

For product and ordering information:

World Wide Web: http://www.usgs.gov/pubprod

Telephone: 1-888-ASK-USGS

For more information on the USGS—-the Federal source for science about the Earth,

its natural and living resources, natural hazards, and the environment:

World Wide Web: http://www.usgs.gov

Telephone: 1-888-ASK-USGS

Suggested citation:

Rosemartin, Alyssa, van Riper III, Charles, 2011, Biological dimensions of tern management-a case study of the least tern in Sonora, Mexico, and a comparative analysis of reproductive investment in terns: U.S. Geological Survey Open-File Report 2010-1085, 27 p.

Any use of trade, product, or firm names is for descriptive purposes only and does not imply endorsement by the U.S. Government.

Although this report is in the public domain, permission must be secured from the individual copyright owners to reproduce any copyrighted material contained within this report. 


\section{Contents}

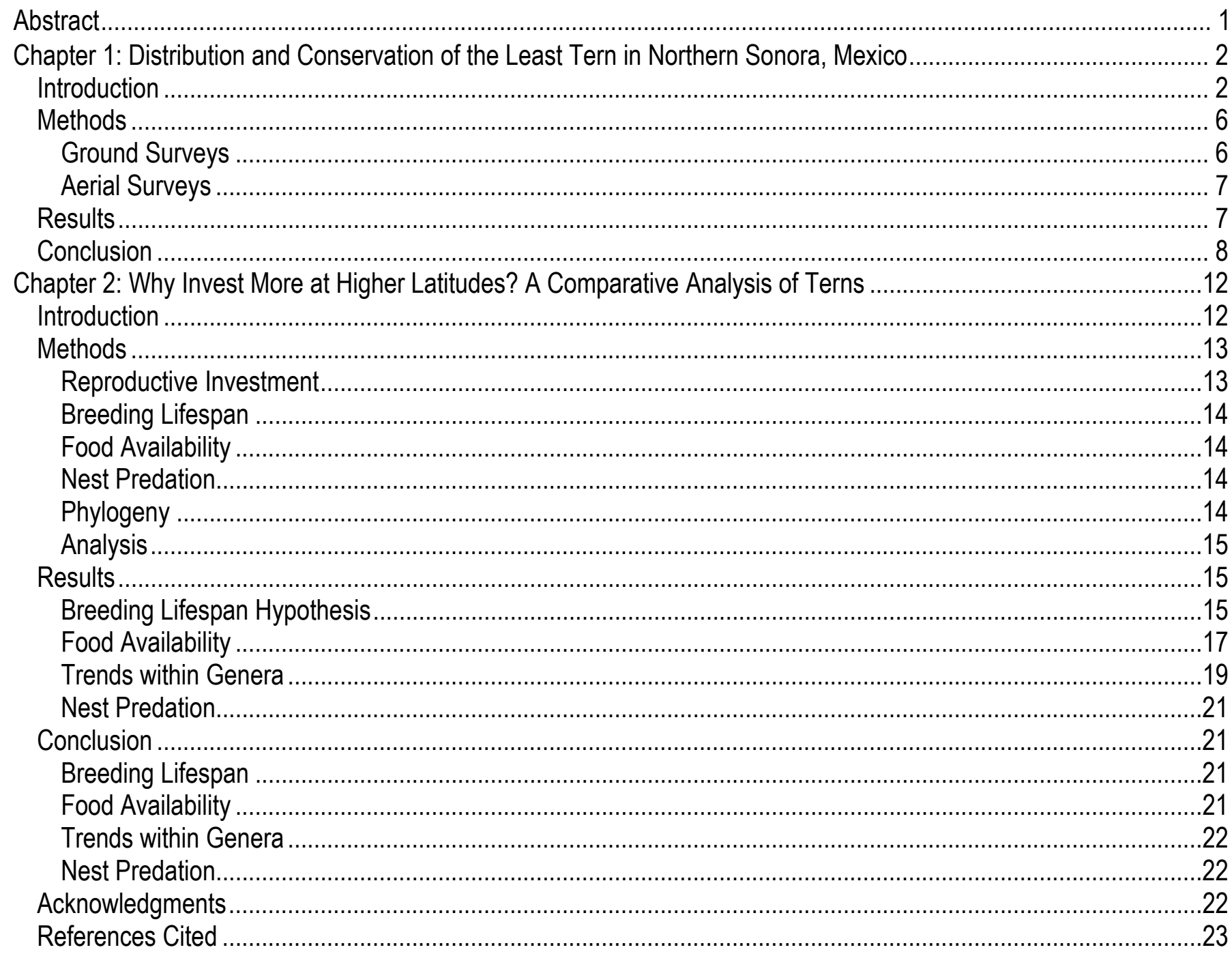

\section{Figures}

1-1. Map of seven large developments north and south of Puerto Peñasco on barrier beaches and peninsulas

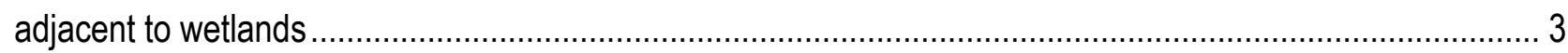

1-2. Typical least tern breeding habitat found at the mouth of the Cerro Prieto estuary ……….................................. 6

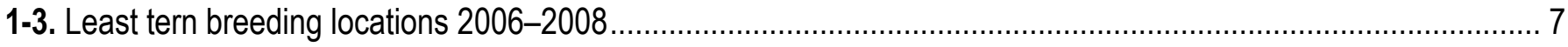

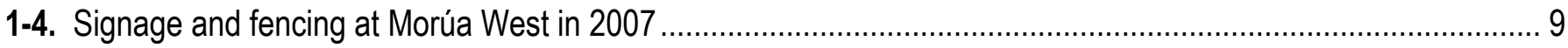

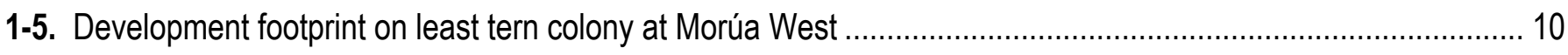

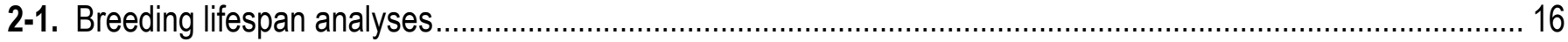


2-2. Breeding lifespan and latitude

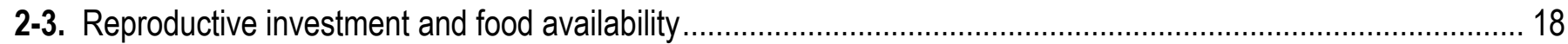

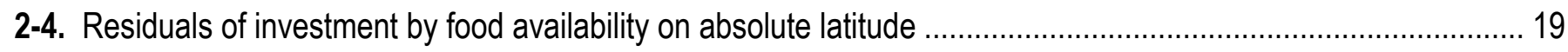

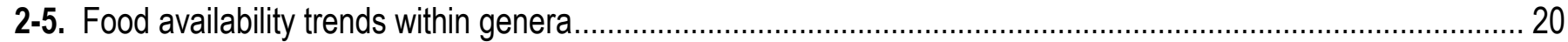

2-6. Nest predation was not related to reproductive investment in raw species or after correcting for phylogeny ...... 21

\section{Tables}

1-1. Level and types of impact to wetlands near Puerto Peñasco ……................................................................. 4

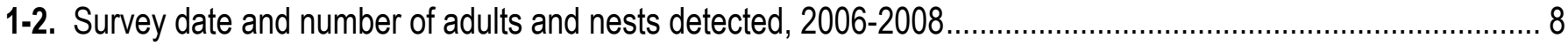




\title{
Biological Dimensions of Tern Management-A Case Study of the Least Tern in Sonora, Mexico, and a Comparative Analysis of Reproductive Investment in Terns
}

By Alyssa Rosemartin ${ }^{1}$ and Charles van Riper III2

\begin{abstract}
Least terns (Sternula antillarum) are threatened by rapid human development on the northern coast of Sonora, Mexico. Terns are bellwethers for changes along the world's coastlines, as their coastal breeding habitat is vulnerable to flooding and development. We conducted targeted ground and aerial surveys for least tern colonies along 160 kilometers of coast, and document our findings on colony sizes at nine sites over 3 years in the first portion of this report. ${ }^{3}$

Like many taxa, terns lay larger clutches at higher latitudes. In the second portion of this report, we evaluate least tern breeding lifespan, food availability, and nest predation as potential ecological reasons behind this differing clutch-size pattern. After correcting for phylogenetic relationships, we found that food availability, not breeding lifespan or nest predation rate, was related to reproductive investment across 46 species and populations of terns. We conclude that coastal development may have a greater impact on nesting terns in tropical regions as compared to temperate breeding locations, because global oceanic patterns of decreased food availability reduce reproductive investment in the tropics.
\end{abstract}

\footnotetext{
${ }^{1}$ University of Arizona, School of Natural Resources, Tucson, Arizona

${ }^{2}$ U.S. Geological Survey, Southwest Biological Science Center, Sonoran Desert Research Station, Tucson, Arizona

${ }^{3}$ This study was part of a cooperative research effort on terns by the U.S. Geological Survey and the conservation and research team of the Intercultural Center for the Study of Deserts and Oceans (CEDO). This collaborative research was undertaken to inform managers and land-use planners about distribution patterns of least terns in Sonora, Mexico, and was part of Alyssa Rosemartin's thesis for her master's degree. Alyssa's work on her thesis was supported by U.S. Geological Survey funding at the University of Arizona.
} 


\section{Chapter 1}

\section{Distribution and Conservation of the Least Tern in Northern Sonora, Mexico}

\section{Introduction}

Regions under sudden and intense human development pressure are often unprepared to manage rapidly increasing human growth. The Gulf of California, one of the richest marine ecosystems in the world (Roberts and others, 2002), is no exception. The coast of the northern Gulf of California is punctuated with hypersaline wetlands, called negative estuaries. These poorly studied habitats are both fragile and of high environmental and social importance, given their high biodiversity, importance for coastal fish stocks, and role in mitigating the effects of floods and sea-level rise (Brusca and others, 2006; Glenn and others, 2006). As the northern gulf community of Puerto Peñasco has grown rapidly, seven nearby estuaries are under increasing threat. The conservation of these estuaries and the services that they provide is a multidimensional problem whose solution may provide lessons for other rapidly transforming coastlines. Given several key features of wetland ecology and coastal management in Mexico, the least tern (Sternula antillarum), because of its habitat requirements, can serve as a focal species to guide coastal conservation efforts. As a first step to understanding least tern populations in the northern Gulf of California, we assembled information from the literature and conducted field surveys in an effort to determine their distribution and provide an information foundation for future conservation and research.

Mangroves and freshwater wetlands have been extensively studied, and their importance for biodiversity conservation and coastal flood mitigation is recognized worldwide (Simpson and others, 1983; Food and Agriculture Organization of the United Nations, 2007). Negative or hypersaline estuaries provide similar environmental services, but their ecology is poorly understood. (A Web of Science search on 18 July 2008 yielded 4 results for "negative estuary;" 222 results for "hypersaline" paired with "wetland," "estuary," and "lagoon;" and 18,492 results for "estuary.")

Negative estuaries are inverted estuaries in which salinity decreases rather than increases nearer to the open ocean because of limited freshwater flows coupled with high levels of evaporation in the shallow channels (Lavín and others, 1998). Despite the challenges of a saline environment, negative estuaries have biodiversity and nutrient levels similar to those of freshwater wetlands (Brusca and others, 2006). The decay of salt-tolerant plants (halophytes) creates a nutrient-rich mud that supports numerous invertebrate species. Tidal flows create nutrient and trophic interactions with the open ocean (Brusca and others, 2006). The wetlands of the northern gulf function as feeding grounds and nurseries for the fisheries of the region (Calderon-Aguilera and others, 2003). Over 150 species of migratory and resident birds have been recorded in these wetlands (Intercultural Center for the Study of Deserts and Oceans, 2007), including 12 species listed in the Mexican Endangered Species Act as threatened or endangered (Diario Oficial de la Federación, 2000).

Many wetlands face threats from coastal development, which is increasing on a global scale. By 2025, 75 percent of the world's population will live within 200 kilometers of the coast (Hinrichsen, 
1998). The community of Puerto Peñasco, in northern Sonora, Mexico, grew 7 percent annually between 2000 and 2005 (Instituto Nacional de Estadística y Geografía, 2005), slower than the fastest growing cities in the world ( $\sim 10$ percent annually), but significantly greater than the neighboring inland city of Tucson, Arizona, U.S.A. (1.4 percent annually; U.S. Census Bureau, 2008). International tourism is a significant contributor to the growth of Puerto Peñasco, both directly (for example, vacationers, second-home buyers) and indirectly through job creation, which draws nationals from across Mexico. There are currently more than 3,000 condominiums in Puerto Peñasco, while another 14,000 are either in construction or in a planning phase (Centro de Investigación en Alimentación y Desarrollo, 2006).

Beaches and peninsulas adjacent to wetlands are often the first priority for development. Beyond the direct effects of land conversion, development indirectly impacts wetland systems by increasing sedimentation because of construction and off-road vehicle traffic and through contamination from septic tanks (Glenn and others, 2006; fig. 1-1; table 1-1). The development of a coastal highway connecting Puerto Peñasco to southern California has opened formerly inaccessible areas to speculation and development, as well as off-road enthusiasts (Centro de Investigación en Alimentación y Desarrollo, 2006). The spread of development from the urban center of Puerto Peñasco along the coasts is characterized by the selling of formerly communal lands (ejidos) to private developers (Intercultural Center for the Study of Deserts and Oceans, 2007). Ejidos, or land-use cooperatives, once controlled much of the land in Mexico. In 1992 the law changed, enabling ejidos to divide their holdings and sell parcels to private owners on the open market (Thompson and Wilson, 1994).

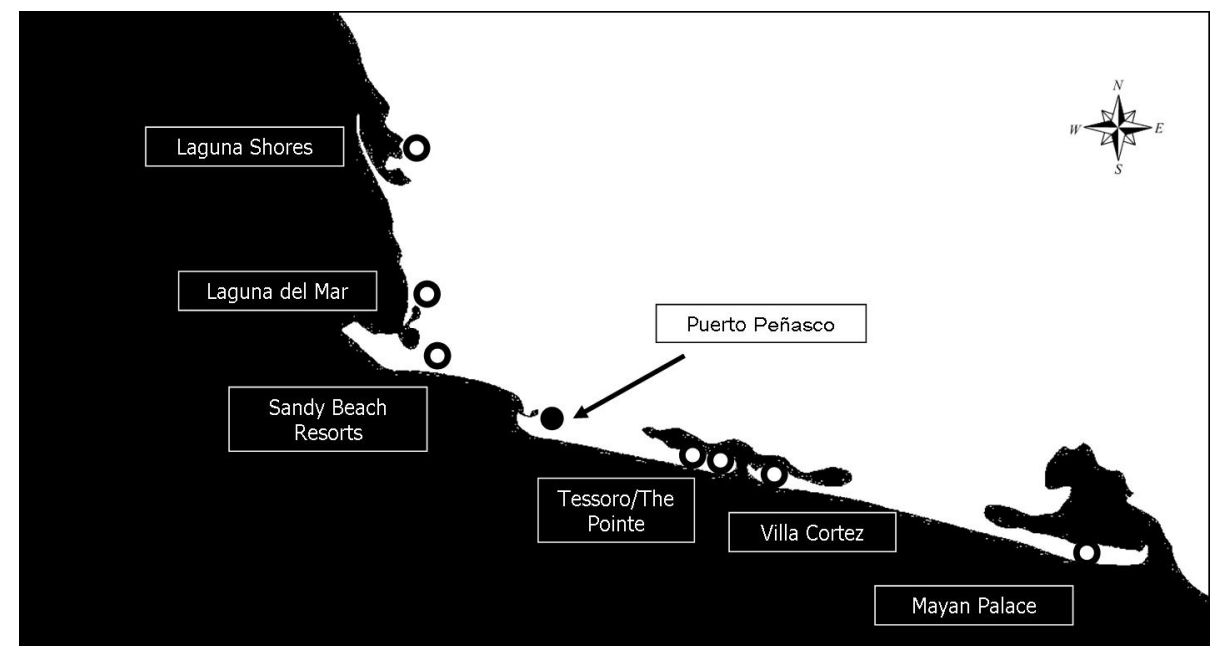

Figure 1-1. Map of seven large developments (circles) north and south of Puerto Peñasco on barrier beaches and peninsulas adjacent to wetlands. 
Table 1-1. Level and types of impact to wetlands near Puerto Peñasco. Note that the most extensive and highest variety of impact is concentrated on the urban center of Puerto Peñasco and diminishes to the north and south. Level and type of impacts from Glenn and others, 2006.

\begin{tabular}{|c|c|c|c|c|}
\hline Name & Latitude and Longitude ( ' ' ") & Area (ha) & Level of Impact ${ }^{1}$ & Type of Impact ${ }^{2}$ \\
\hline Estero San Francisquito & $\begin{array}{l}305628 \mathrm{~N} \\
1130542 \mathrm{~W}\end{array}$ & 543 & 0 & -- \\
\hline $\begin{array}{l}\text { Bahía San Jorge: Salina \& } \\
\text { Almejas }\end{array}$ & $\begin{array}{l}310908 \mathrm{~N} \\
1130354 \mathrm{~W} \\
311552 \mathrm{~N}\end{array}$ & 98,740 & 1 & $\mathrm{~S}$ \\
\hline Estero La Pinta & $\begin{array}{l}1131451 \mathrm{~W} \\
311709 \mathrm{~N}\end{array}$ & 3,338 & 2 & $\mathrm{R}, \mathrm{C}$ \\
\hline Estero Morúa & $\begin{array}{l}1132619 \mathrm{~W} \\
311824 \mathrm{~N}\end{array}$ & 1,097 & 2 & $\mathrm{R}, \mathrm{C}, \mathrm{S}$ \\
\hline Puerto Peñasco & $\begin{array}{l}1133259 \mathrm{~W} \\
312048 \mathrm{~N}\end{array}$ & 0 & 3 & $\mathrm{C}, \mathrm{S}$ \\
\hline Estero La Cholla & $1133635 \mathrm{~W}$ & 235 & 3 & $\mathrm{C}, \mathrm{R}$ \\
\hline Estero Cerro Prieto & $\begin{array}{l}312531 \mathrm{~N} \\
1133712 \mathrm{~W} \\
313554 \mathrm{~N}\end{array}$ & 1987 & 1 & $\mathrm{~S}$ \\
\hline Esteros de la Bahía Adaír & $1135615 \mathrm{~W}$ & 29226 & 0 & -- \\
\hline
\end{tabular}

1 "The extent of human impact on each wetland was rated from 0 to 3: 0 is no apparent impact; 1 is some human impact evident but the wetland appears intact; 2 is the wetland has been altered by reduced freshwater flows, extensive resort development or aquaculture, but appears mostly intact; 3 is $>50 \%$ of the wetland has been converted to other uses." (Glenn and others, 2006)

2 "Codes for types of development: shrimp farms on margins of the marsh (SF); resort and vacation homes on margins (R); local settlements on margins (S); diversion of freshwater flows from rivers (D); and clearing of marsh area for development(C)." (Glenn and others, 2006)

The changed legislation has allowed for increased coastal development in Mexico, although not in mangrove wetlands, which were given special protection by the NOM-ECOL-022-2003. Nonmangrove wetlands, as a natural resource, are protected by the Ley General de Equilibrio Ecológico y la Protección al Ambiente (LGEEPA) passed in 1988, a parallel to the National Environmental Policy Act (NEPA) in the United States (Gonzalez and Gastelum, 1999). The law requires the Federal government to review and regulate environmental impacts. LGEEPA requires environmental impact statements for major actions affecting a natural resource (Diario Oficial de la Federación, 2007).

While LGEEPA appears to be a powerful resource management law, a lack of enforcement undermines the system. For example, several of the estuaries near Peñasco are slated for conversion to marinas by the Escalera Náutica (Nautical Stairway) project, coordinated by the National Tourism Fund. The project aims to increase yacht and cruise ship tourism in the gulf by building a series of marinas and investing in coastal towns. The original impact statement for the entire project was approved by the Secretariat of Natural Resources (SEMARNAT) without identifying the dozens of estuaries chosen for conversion. A Mexican Supreme Court decision in 2003 required an impact statement for each marina 
(Kastelein, 2003). As in the United States, the Endangered Species Act in Mexico provides habitat-level protection for listed species. Impacts to endangered species must be described and mitigated in the environmental review context (Diario Oficial de la Federación, 2000).

The political, social, legal, and biological factors at play in wetland conservation in the northern Gulf of California govern the effectiveness of using focal species to guide preservation and conservation efforts. A focal species should effectively represent ecosystem needs, commercial values, and cultural values, and should be afforded legal protection. The least tern is a logical focal species because it depends on juvenile fish in coastal wetlands, breeds in sites highly vulnerable to coastal development, and is protected under the Mexican Endangered Species Act. To accurately and effectively inform coastal planning, basic information on the species' abundance and distribution is required.

Least tern life history is well studied in the United States (Massey, 1974; Thompson and others, 1997). Like other terns in the genus Sternula, least terns are small (40 g) and a relatively long-lived species, with an average life span of 12.6 years, with 9.6 reproductive years (Massey, 1974). Least terns winter in northern South America and breed from April to August in North America on the Atlantic and Pacific coasts and on the waterways of the central United States. Least terns typically lay two eggs in coastal regions, which hatch in 3 weeks (Thompson and others, 1997). Young leave the nest after 2 days, fledge at 3 weeks, and are fed by their parents for several more weeks, becoming fully independent before migrating south in August and September (Thompson and others, 1997). Least terns consume small schooling fish (for example, silversides [Leuresthes sardine] and [Colpichthys regis] and anchovies [Anchoa spp.]; Zuria and Mellink, 2005) to bring to their young. In the northern Gulf of California, least terns are known to nest and feed adjacent to and within coastal wetlands (Alcock, 1992; Mellink and Palacios, 1993).

Least terns choose colony sites based on: (1) fidelity to sites where previous reproductive efforts have been successful, (2) natal site fidelity, (3) conspecific attraction, and (4) physical qualities of the site (Thompson and Slack, 1982; Gochfeld, 1983; Kotliar and Burger, 1986). Least terns typically nest less than 1 meter above sea level, preferring sites that are flat, are close to open water, and have little vegetation (Thompson and Slack, 1982; Gochfeld, 1983; Kotliar and Burger, 1986; Mazzocchi and Forys, 2005). They select sandbars or open beaches, shellpiles or small sandbars in mudflats, salt flats, and dredge-spoil islands (Palacios and Mellink, 1996). Terns seem to trade off the risk of flooding (low elevation) with the risk of nest predation (vegetative cover for predators increases with elevation; Thompson and Slack, 1982).

The locations favored by terns for nesting are also favored for human recreation and development, leading to a conflict that often results in reproductive failure for the terns (Gochfeld, 1983; Zuria and Mellink, 2002) and pushes colonies closer to the water. Given that colonies suffer near complete failure following extreme tides (Zuria and Mellink, 2002), displacement of colonies toward the sea could result in dramatic reductions in recruitment, an effect potentially exacerbated by rising sea levels predicted by climatologists (Intergovernmental Panel on Climate Change, 2007; Rahmstorf, 2007). Failure of Caspian tern (Sterna caspia) colonies in marginal habitat has been attributed to the effects of climate change in Alaska, U.S.A. (Gill, 2008). This combination of factors makes identifying and protecting suitable least tern habitat a conservation priority in the Gulf of California.

Starting in 1991, parts of the northern coast of Sonora were surveyed for least terns but only intermittently and over a limited area. A colony at La Purinera with an estimated 200 nesting pairs was recorded in 1991, 1992, 1995, 2002 and 2005 (see fig. 1-3 for colony locations; Mellink and Palacios, 1993; Palacios and Mellink, 1996; Zuria and Mellink, 2002; Zuria and Mellink, 2005). The area was not surveyed previously or in intervening years. Two small colonies (Morúa East and West) were recorded in 1992 (Alcock, 1992; Mellink and Palacios, 1993). 
Current and previous occupancy of potential colony sites in the estuaries of Almejas, La Pinta, Cholla Bay, and Cerro Prieto and in the Bahía Adair wetland complex has not been studied. Two pairs nested in salt flat west of Bahía Adair in 1991, and one pair was seen in 1992 (Mellink and Palacios, 1993). Bahía Adair is considered a potentially important nesting area for least terns, although colony sites have not been identified (Brusca and others, 2006). Two other small colonies were recorded in 1991 and 1992, one in Estero San Francisquito, adjacent to San Jorge, and one in Estero Los Tanques, 60 kilometers to the south. No other information is available on distribution of least tern colonies on the coast of Sonora (Russell and Monson, 1998). We undertook a complete and continuous survey of the region in order to fill in the gaps in the current knowledge of tern distribution.

\section{Methods}

We surveyed 160 kilometers of coastline from Bahía San Jorge in the south to Bahía Adaír in the north for breeding least terns. Based on local knowledge of the area and satellite images (GoogleEarth and Instituto Nacional de Estadística y Geografía), survey locations with the following range of characteristics were selected: flat, sparsely vegetated sandbars, spits, shellpiles, and salt flats located within 1.5 meters of sea level at mean high tide, within 3 kilometers of open water, and with less than 15 percent vegetative cover (see fig. 1-2, for example). Surveys were conducted from April to June in 2006-2008. We conducted ground surveys of 4 sites in 2006, 10 sites in 2007, and 3 sites in 2008. Each site was surveyed once each year with the following exceptions: Morúa West, 2006, twice; Morúa East, 2007, three times; La Cholla, 2007, three times; La Purinera, 2008, three times; Morúa East, 2008, nine times. In 2008, we also conducted an aerial survey of the 160 kilometers of coast in the study area.

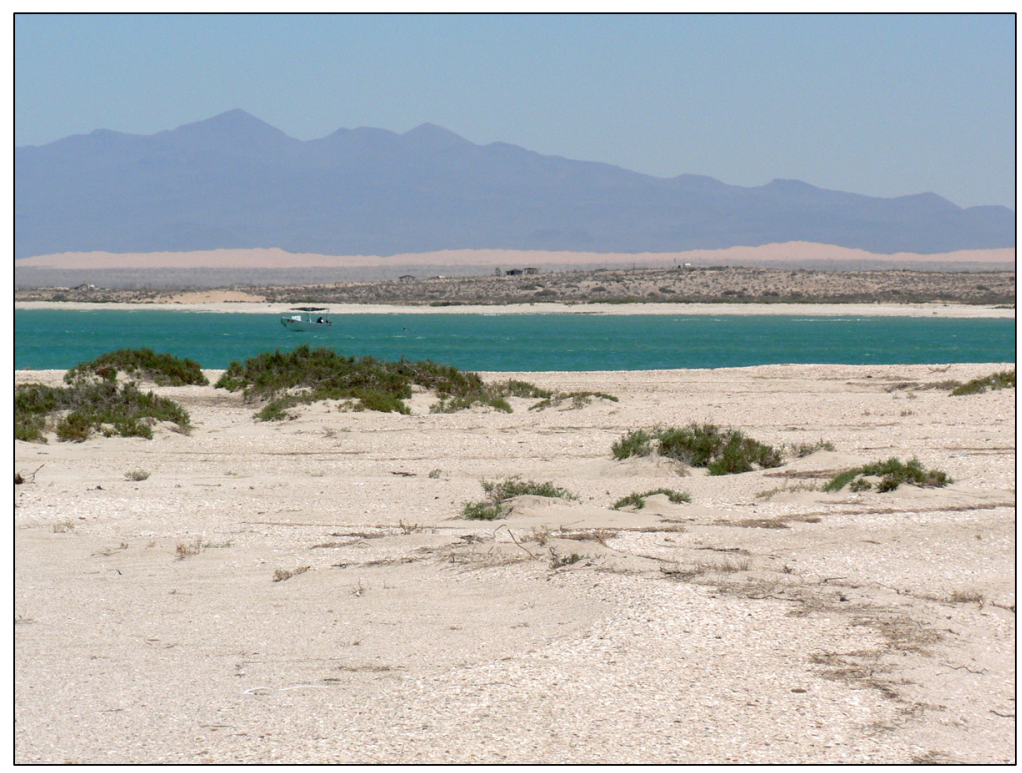

Figure 1-2. Typical least tern breeding habitat found at the mouth of the Cerro Prieto estuary.

\section{Ground Surveys}

Observers walked, drove, or travelled by boat along the 160 kilometers of coastline in the study area. They searched for appropriate habitat as defined above and for adult least terns. When nesting activity was encountered, inconspicuous observation areas were established from which observers had an uninterrupted view of the colony area. Two observers, equipped with $8 \times 42$ binoculars, recorded the number of nests, juveniles, and adults and mapped nest sites on a paper grid. Total colony area was 
determined by taking GPS locations every 20 meters along the colony perimeter. If colony area was larger than $200 \times 100$ meters, observers divided the colony into sections of roughly $200 \times 100$ meters each, using GPS and laser range finder to determine the appropriate area and survey each section as described above.

\section{Aerial Surveys}

Two observers flew in a Cessna 182 from Bahía San Jorge to Bahía Adair (lat $30^{\circ} 53^{\prime \prime}$ N., long $113^{\circ} 05^{\prime \prime} \mathrm{W}$. to lat $31^{\circ} 29^{\prime \prime} \mathrm{N}$., long $114^{\circ} 04^{\prime \prime} \mathrm{W}$.). Observers and pilot searched for flat, sparsely vegetated sandbars, spits, shellpiles, and salt flats within 0 to 1.5 meters of the high-tide line and within 3 kilometers of open water. When a least tern was observed flying, standing, or sitting over sand, the plane circled back and flew a longitudinal transect at $\sim 160 \mathrm{kph}$ at an altitude of 60 to 150 meters on the coastal side of the potential colony area. Equipped with $8 \times 42$ binoculars, two observers independently counted the number of terns standing, sitting, or flying over land at every site and recorded the GPS location and altitude of each survey.

\section{Results}

Some locations identified with satellite imagery as appropriate habitat were deemed inappropriate during ground surveys, while other locations appeared appropriate in both images and surveys but were not found to be occupied by least terns during surveys. The main sandbars of Almejas and La Pinta estuaries appeared appropriate in the images, but on surveys were found to have uneven terrain or heavy vegetative cover. Large salt flats southeast of Almejas and around Bahía Adair are considered appropriate least tern nesting habitat, but no evidence of nesting was observed. All other sites that were identified through satellite imagery were suitable habitat (as defined above) and occupied in at least one year of this study by nesting least terns (fig. 1-3). For all surveys, we report numbers of adults and nests observed at each colony site (table 1-2).

The average difference between the two observers counts during aerial surveys was $3.1( \pm 4)$ terns per colony. Aerial surveys were similar to ground surveys: La Purinera (ground 46, aerial 46) and Morúa East (ground 14, aerial 11).

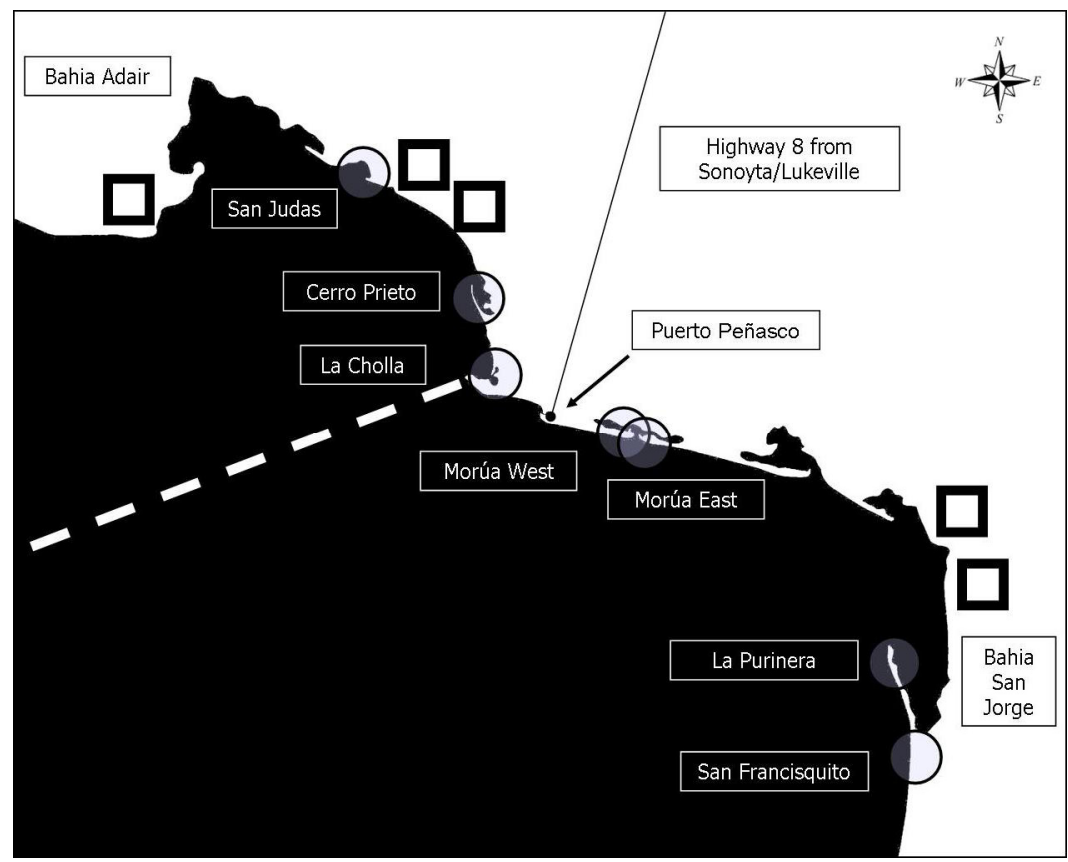

Figure 1-3. Least tern breeding locations 2006-2008. Circles are centered on sites occupied in at least one year, 2006-2008. Site names are given in white text. Squares indicate salt flats where no evidence of nesting was found. Region above the dotted line lies within the Upper Gulf of California and Colorado River Delta Biosphere Reserve. 
Table 1-2. Survey date and number of adults and nests detected, 2006-2008. Cerro Prieto I: main sandbar; Cerro Prieto Il: small sandbars in marsh. 2008 aerial survey (final column) conducted May 15. Means rounded to the nearest whole tern (ND: No Data).

\begin{tabular}{|c|c|c|c|c|c|c|c|c|c|c|c|c|c|c|}
\hline & 2006 & Ground & & 2007 & Sround & & 2008 & Bround & & $\begin{array}{l}\text { Adult } \\
\text { means }\end{array}$ & & $\begin{array}{l}\text { Nest } \\
\text { means }\end{array}$ & & $\begin{array}{l}2008 \\
\text { Flights } \\
\end{array}$ \\
\hline Site & Date & Adults & Nests & Date & Adults & Nests & Date & Adults & Nests & Mean & \pm & Mean & \pm & Adults \\
\hline $\begin{array}{l}\text { San } \\
\text { Francisquito }\end{array}$ & ND & ND & ND & $5 / 28$ & 14 & 3 & ND & ND & ND & 14 & ND & 3 & ND & 15 \\
\hline La Purinera & $5 / 16$ & 324 & 108 & $5 / 29$ & 134 & 85 & $\begin{array}{l}5 / 10 \\
6 / 14\end{array}$ & 46 & 117 & 168 & 142 & 103 & 17 & 46 \\
\hline Morúa East & $6 / 3$ & 28 & 7 & $5 / 6$ & 19 & 9 & $\begin{array}{r}5 / 17 ; \\
5 / 22\end{array}$ & 15 & 22 & 21 & 7 & 13 & 8 & 11 \\
\hline Morúa West & $6 / 2$ & 51 & 19 & $5 / 26$ & 8 & 1 & ND & ND & ND & 30 & 30 & 10 & 13 & 10 \\
\hline $\begin{array}{l}\text { La Cholla } \\
\text { Cerro Prieto }\end{array}$ & ND & ND & ND & $5 / 18$ & 26 & 13 & $5 / 4$ & 3 & 1 & 15 & 16 & 7 & 8 & 8 \\
\hline $\begin{array}{l}\text { I Cerro Prieto } \\
\text { Con }\end{array}$ & ND & ND & ND & $5 / 30$ & 0 & 0 & ND & ND & ND & 0 & ND & 0 & 0 & 16 \\
\hline & $5 / 20$ & 18 & 3 & $5 / 30$ & 5 & 5 & ND & ND & ND & 12 & 9 & 4 & 1 & 0 \\
\hline San Judas & ND & $\mathrm{ND}$ & $\mathrm{ND}$ & $6 / 5$ & 3 & 1 & ND & ND & ND & 3 & ND & 1 & $\mathrm{ND}$ & 0 \\
\hline Totals & & & & & & & & & & 263 & & 141 & & \\
\hline
\end{tabular}

\section{Conclusion}

Based on 3-year averages of the number of nests detected, at least 141 least tern pairs $( \pm 47)$ breed in the study area. A less precise estimate, based on 3-year averages of number of adults detected, is $261( \pm 204)$ pairs (given that a 1:1 individual observed to pair ratio has been found in terns, where one adult is often feeding while the other incubates or defends the colony; U.S. Geological Survey, 1997). One hundred forty-one pairs represent a significant proportion of the 400 estimated pairs in the Gulf of California (Palacios and Mellink, 1996).

La Purinera is one of only two known colonies with more than 100 pairs in the entire Gulf of California (Palacios and Mellink, 1996). The change in individuals present at La Purinera falls within the range of recent interannual fluctuations at this site (60 to 240 pairs; Palacios and Mellink, 1996; Zuria and Mellink, 2005). While only 46 adults were present at La Purinera in mid-May 2008, the number of nests by mid-June had risen to 117. Flooding and sand storms at the colony in early May likely destroyed at least 50 nests and may have caused partial colony failure; this was followed by a wave of re-nesting. However, multiple surveys per season during nesting peaks are required for more precise estimates of colony size (Steinkamp and others, 2003).

Some sites (San Judas, Cerro Prieto) were not occupied in all years of this study, confirming the need to manage "clusters" of alternate sites (Massey and Fancher, 1989; Palacios and Mellink, 1996). In addition, the conservation of multiple populations is a central tenet of conservation biology and has been found to exponentially decrease the risk of species extinction in interior least terns (Sterna antillarum athalassos) (Boyce and others, 2002). Sites that constitute good habitat and have been occupied in at least one year are important for the species persistence in this region.

Three previously unrecorded colonies (La Cholla, Cerro Prieto, and San Judas) are documented in this report. Two sites (La Pinta and Almejas) that were identified in satellite images and appeared suitable for habitat were found to consist of uneven terrain and were not occupied by least terns. Aerial and ground surveys did not reveal additional suitable habitat sites beyond those already identified using 
satellite images. This suggests that least tern nesting habitat likely can be identified from satellite images.

We were able to identify causes of reproductive failure at some colonies. The colony at Morúa East fledged no young in 2007 because of flooding during a high tide on 31 May. The Morúa West colony declined from 12 nests to 1 from 2006 to 2007. The decline is likely because of the preconstruction phase of five condominium towers that eliminated a portion of the former nesting habitat. A portion of the colony was directly affected by clearing and reshaping of dunes, which took place in 2007. The remainder of the colony was given greater protection from off-road vehicles and pedestrians by signage and fencing put in place by the developers (fig. 1-4). However, this effort did not support breeding activity (fig. 1-5).

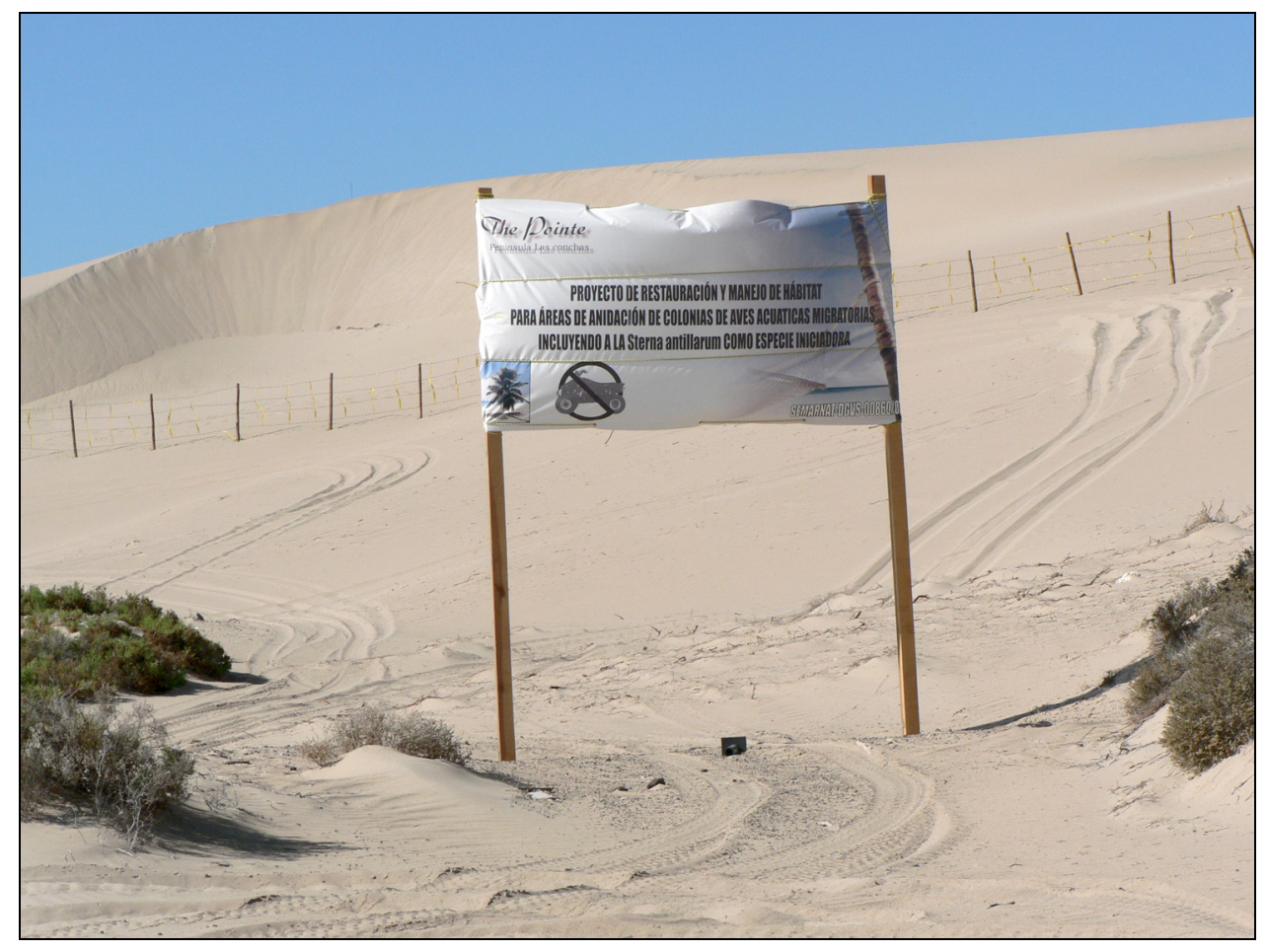

Figure 1-4. Signage and fencing at Morúa West in 2007. Actions taken by developers may have reduced smallerscale impacts (from off-road vehicles and pedestrians) to the tern colony, but the destruction of the dunes, seen behind the sign, likely deterred terns from using this site in 2007. 


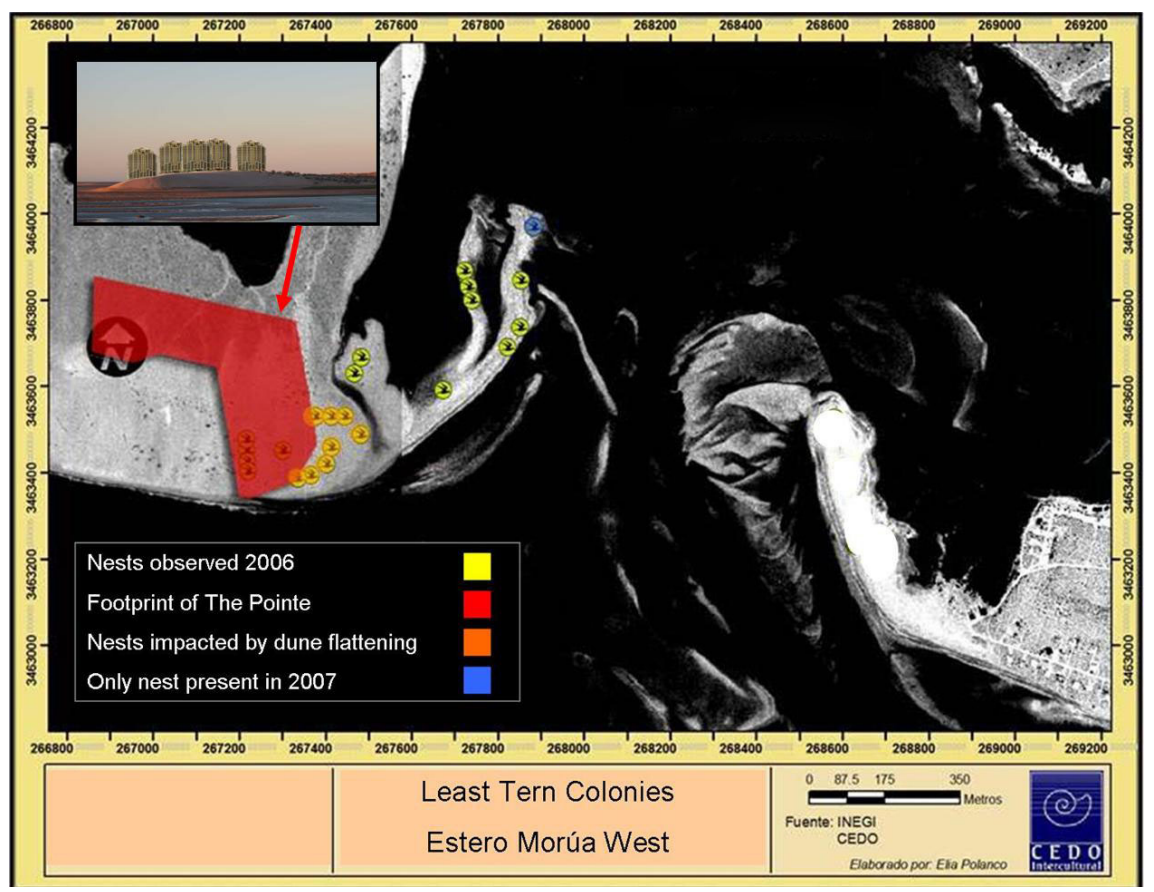

Figure 1-5. Development footprint on least tern colony at Morúa West. Overlay of least tern nests in 2006 and 2007 and planned footprint of the development "The Pointe" on an Instituto Nacional de Estadística y Geografía satellite map of Estero Morúa (base map: Elía Polanco).

After extensive development in coastal California caused the California least tern (Sternula antillarum browni) population to decline to 600 pairs, the species was listed as endangered (U.S. Fish and Wildlife Service, 1985). The population has increased to 7,100 pairs (U.S. Fish and Wildlife Service, 2006) but remains listed as endangered and requires intensive management. At Camp Pendleton, a military installation in San Diego that contains 17 percent of the population of California least terns, annual management costs over \$150,000 each year (Shwiff and others, 2005).

Limited habitat may have changed the spacing of least tern nests in California (Collins, personal commun.). Inter-nest distance for California least terns is estimated at 3 meters (Massey, 1974; Gilligan, unpub. data), while we found an average inter-nest distance of 34.75 meters $( \pm 5.96)$. Decisionmakers in the Gulf of California have an opportunity to plan coastal growth to avoid changes to reproductive biology and impacts to the habitat of endangered species (Zedler, 1996).

Principal threats to the least tern in the study area are flooding, direct habitat loss through development, and disturbance from increased pedestrian and off-road vehicle traffic (Palacios and Mellink, 1996; Zuria and Mellink, 2005). We found more and larger colonies south of Puerto Peñasco, and outside of the Upper Gulf Biosphere Reserve. This finding should help managers decide if there is a need for additional protected areas and mitigation for development impacts outside of the present biosphere reserve.

Least terns breed somewhat asynchronously, making colony size estimates difficult without several surveys throughout the breeding season (Zuria and Mellink, 2002). While our data accurately represent colony occupancy and minimum number of adults and nests present each year during this study period (2006-2008), maximum colony size can only be estimated through repeated visits throughout the season. Given their efficiency, yearly aerial surveys to determine colony occupancy and to provide a "snapshot" of colony size would be useful. The colonies under the most intensive 
development pressure (Morúa East and West and La Cholla) would seem to merit ground monitoring throughout the breeding season, as would the large and continuously occupied colony at La Purinera in Bahía San Jorge because of its potential importance to the population of least terns in Sonora and the Gulf of California. Fledging rate is a more sensitive parameter to population declines than adult population size, given that least terns are a long-lived species. Our study updates information on the status of the least tern in northern Sonora, and hopefully will serve as a foundation for the design of a long-term monitoring program and better inform regional planners about least tern distribution patterns. 


\section{Chapter 2}

\section{Why Invest More at Higher Latitudes? A Comparative Analysis of Terns}

\section{Introduction}

Organisms from arthropods to songbirds produce larger clutches at higher latitudes (Fox and Czesak, 2000; Hemborg and others, 2001). The reasons behind this pattern remain unclear. Within and across species, birds produce larger clutches relative to adult body mass at temperate compared to tropical latitudes (Skutch, 1949; Hockey and Wilson, 2003; Martin and others, 2006). Reproductive investment (considered here as clutch mass relative to adult body mass) is under intense selective pressure, given the high cost of egg production and the direct relationship between investment and individual fitness (Roff, 1992). Why would species increase investment in reproduction at higher latitudes?

Gulls and terns have high clutch mass relative to body size and depend on current rather than stored energy for reproduction (Moore and others, 2000). Marine-nesting terns and noddies in the subfamily Sterninae are a good study system for this question because they have a global breeding distribution and share a suite of life history traits (colonial breeding at sites not defended in the nonbreeding season; feeding on small oceanic fish and crustaceans; semi-precocial young [Burger and Gochfeld, 1991; Weimerskirch, 2001]). The clutch mass of marine-nesting terns ranges from 14 to 42 percent of adult body mass. This range is greater than the reported range of reproductive investment for eight families of turtles and three families of snakes, while three snake families and the Lycosidae spider family show similar ranges of reproductive investment.

Across 34 of the 45 species of terns, clutch size and egg mass increase with latitude, after correcting for adult body mass (Hockey and Wilson, 2003). However, this analysis did not correct for phylogenetic relationships, account for latitudinal variation in reproductive investment within species, or evaluate explanations for this pattern. Tern clutch size and egg volume do vary within species across latitude (Nelson, 1980).

Life-history theory predicts that a reduction in lifetime breeding opportunities will result in increased investment at each opportunity (Roff, 1992; Ekman and Askenmo, 1986). Temperate nesting terns may have a reduced lifetime breeding lifespan because of higher adult mortality (Faaborg and Arendt, 1995), perhaps owing to higher costs of migration and temperature regulation (Weimerskirch, 2001). Consistent with a longer breeding lifespan in the tropics, tropical-nesting pelicaniforms have been found to begin breeding later than their temperate counterparts (Nelson, 1983). If breeding lifespan in terns decreases with increasing latitude, one would expect a negative correlation between the length of breeding lifespan and reproductive investment.

Reproductive investment in terns may be related to food abundance (Suddaby and Ratcliffe, 1997; Monaghan and others, 1989), which increases with latitude in marine ecosystems (Thurman, 1997). Spatial and temporal peaks in food availability are critical in colonial breeders where synchronous hatching creates a dependence on localized food abundance (Ricklefs, 1983). If food 
availability increases with latitude, one would expect a positive correlation between food abundance and reproductive investment in terns.

Variation in predation on eggs or young across latitude may also explain patterns of reproductive investment (Stearns, 1992). Increased clutch size with latitude in land birds has been attributed to higher levels of nest predation in the tropics (Martin and others, 2006). High predation might lead to lower reproductive investment (Fontaine and Martin, 2006). An individual bird that invests less in its initial clutch will have a larger reserve for second and third nesting attempts (Slagsvold, 1982). Other mechanisms proposed to explain the relationship between reproductive investment and nest predation in songbirds (larger clutches are more likely to be detected by predators and require more frequent conspicuous feeding forays by parents; reviewed in Slagsvold, 1982) are not likely operating in colonial seabirds, which rely more on predator swamping and group defense than on nest concealment (Hamer and others, 2001). If nest predation declines with latitude, one would expect a negative relationship between nest predation rate and reproductive investment.

We propose and test four hypotheses to explain the latitudinal increase in reproductive investment in marine-nesting terns: (1) a reduction of breeding lifespan with latitude, (2) an increase in food availability with latitude, (3) a reduction of nest predation rate with latitude, and (4) the conservation of the traits related to reproductive investment through phylogenetic inertia. The consideration of these hypotheses in a comparative framework, across species, allows insight into evolved responses to ecological pressures.

\section{Methods}

We conducted an extensive literature search to test each of the four alterative hypotheses to explain the latitudinal gradient in reproductive investment across species. We compiled data on tern egg mass, clutch size, adult mass, age at first reproduction, longevity, annual adult survivorship, and nest predation rate at one or more latitudes within a species' breeding range from 133 published articles and books and two unpublished datasets. In 10 species, only one complete set of the parameters at a given latitude was available. In 14 species, complete datasets on discrete population segments are included, resulting in 35 records. Population segments were characterized by discrete breeding ranges, separated by at least 15 degrees latitude or longitude ( 1,600 kilometers). Dispersal of individuals between population segments is unlikely, as site fidelity is high in terns (Atwood and Massey, 1988; Solis and others 1999; Spendelow and others, 1995). In addition, 17 of these 35 population-level records are recognized subspecies.

\section{Reproductive Investment}

When multiple data points for egg mass, clutch size, adult mass, and/or survivorship were available across latitude within a species or population segment, we regressed the species' parameters on absolute latitude. If the regression yielded a good fit $\left(\mathrm{R}^{2}>0.80\right)$ or a significant relationship $(p<0.05)$, we extrapolated the biological parameter at a median latitude. If no fit emerged from the analysis, we took a weighted average (by study sample size) for the parameter at median latitude. Species for which a complete reproductive dataset was not available were excluded.

We used egg mass as reported in the literature when available for 20 of 64 egg-mass records. We then created the equation Length $\mathrm{x} \mathrm{Width}{ }^{2} / 0.00195$ to calculate mass for 41 records. To create the equation, we used six records (from six tern species across a wide egg-mass gradient) that gave both fresh egg mass and dimensions (339 eggs) and an additional seven records that gave dimensions and mass as calculated using a 13 variable formula (Schonwetter, 1960). Both of these methods yielded a 
similar divisor, $Y,(0.00193( \pm 0.00007)$ and $0.00195( \pm 0.00003)$, respectively $)$, in the equation: Length $\mathrm{x} \mathrm{Width} / \mathrm{Y}$. We then considered an additional 10 records where egg dimensions and mass were available at a given location but not within the same study, yielding a divisor, Y, of 0.00198 ( \pm 0.00018). Divisors from these three sources were averaged to create the 0.00195 divisor.

In three cases, we used measures of volume as equivalent to mass, where mass was not available or calculable from dimensions. Three sources gave egg mass and volume for the same eggs (361 eggs), which showed a 1.00:1.00 $( \pm 0.08)$ ratio of egg volume to mass. Density of fresh common tern eggs has been found to be $1.0058 \mathrm{~g} / \mathrm{ml}$ (Rahn and others, 1976). Clutch size, egg mass, and adult mass were used to calculate percent clutch mass per unit adult mass as a measure of reproductive investment.

\section{Breeding Lifespan}

We considered three proxies for the number of lifetime breeding opportunities: age of first reproduction, difference between longevity record and age of first reproduction, and annual adult survivorship. Terns nest annually and re-nesting only occurs after nest failure (Hamer and others, 2001). Banding records were used for longevity (Klimkiewicz, 2008), while data on annual adult survivorship were taken from mark-recapture studies.

\section{Food Availability}

Marine-nesting terns feed primarily on small fish (Zuria and Mellink, 2005; Nelson, 1980), which can be difficult to quantify and compare across sites. Oceanic net primary productivity (NPP) is correlated to the abundance of small fish, upon which terns feed (Aebischer and others, 1990), and has been shown to predict breeding performance in roseate terns (Sterna dougallii) (Monticelli and others, 2007). We obtained estimates of NPP based on satellite imagery (Oregon State University, 2008). The Vertically Generalized Production Model is used to estimate NPP based on remotely sensed chlorophyll concentration, light availability, and sea-surface temperature estimates (Behrenfeld and Falkowski, 1997). Input data under cloud cover was filled by gap-filling software at Oregon State University, and monthly climatologies were constructed from the resulting NPP data. Tern breeding locations were rounded to the nearest degree of latitude and longitude. We calculated an average breeding season NPP value for the degree block of latitude and longitude surrounding the breeding location, from monthly 10year averages (1997 to 2007). Values for the whole months in each species' reported breeding season were then averaged.

\section{Nest Predation}

We used the number of nests reported as fully or partially depredated at either the egg or the chick stage relative to the number of nests followed in a study as a measure of predation rate (percent). When more than one predation rate was reported for a species in a given region, we averaged the values. In three cases, we relied on the source publication's stated assumption that missing eggs or chicks had been depredated.

\section{Phylogeny}

We used a phylogeny inferred from mitochondrial DNA for relationships and divergence times among terns (Bridge and others, 2005), assuming a one million year divergence time for all subspecies, based on a subspecific pair that was found to have diverged one million years ago (Bridge and others, 2005). Monotypic population segments were set at divergence times of 0.05 million years. For three species, complete datasets for more than two within species populations were available. In order to 
avoid polytomies in the contrast analysis, which are averaged to the node, we created a species pair and an outgroup for each group of three, based on geographic distance between breeding populations.

\section{Analysis}

We modeled the association between the explanatory variables and reproductive investment in both raw species analyses and phylogenetically independent contrasts, and then analyzed the full tree (which includes population-level records; $n=45)$ and a reduced tree including only hard species $(n=24)$. We used the PDAP (Midford and others, 2005) module of the program Mesquite (Maddison and Maddison, 2004) to calculate contrasts. While divergence times in millions of years were available, analyses were run with branch lengths set to one. When the contrast values of the branch lengths in millions of years were plotted against their standard deviations, a significant slope was apparent, indicating that the contrasts were not appropriately standardized for analysis (Garland and others, 1992). The proportion of clutch mass per unit adult mass (percent) and nest predation rate (percent) were arcsine square root transformed, and both NPP (mg Chlorophyll), age of first reproduction (years) were log-transformed, to comply with assumptions of homogeneity of variance. We constructed least squares regression for both raw species and independent contrasts (which were forced through the origin), with JMP statistical software program (JMP IN 5.1, 2005). In that we were testing directional a-priori predictions, we report one-tailed $t$-tests.

\section{Results}

\section{Breeding Lifespan Hypothesis}

Adult survivorship, age of first reproduction, and the difference between longevity and age of first reproduction were not correlated with reproductive investment in raw species analysis (fig. 2-1a, b, and $\mathrm{c}: \mathrm{t}_{14}=0.44, p=0.334 ; \mathrm{t}_{19}=0.34, p=0.371 ; \mathrm{t}_{15}=0.39, p=0.351$, respectively), after correcting for phylogeny, (fig. 2-1d, e, and f: $\mathrm{t}_{13}=-0.43, p=0.338 ; \mathrm{t}_{18}=-0.33, p=0.373 ; \mathrm{t}_{14}=-0.23, p=0.413$, respectively), and when considering hard species only (Raw: $\mathrm{t}_{9}=-0.02, p=0.491 ; \mathrm{t}_{11}=0.17, p=0.434 ; \mathrm{t}_{14}=1.38, p=0.102$, respectively). The difference between longevity and age of first reproduction did decline with absolute latitude (fig. 2-2: $\mathrm{t}_{10}=-3.28, p=0.006$ ). 

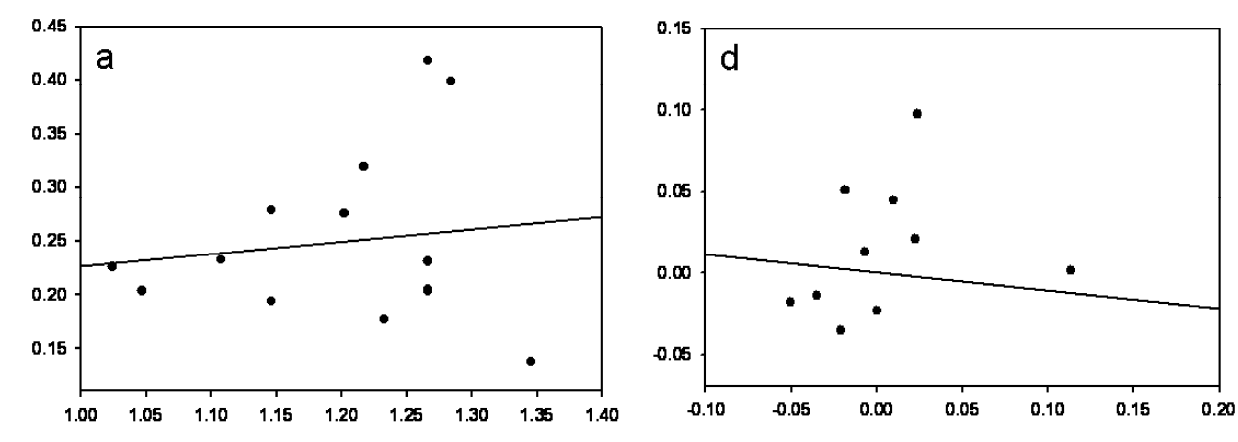

Annual Adult Survivorship
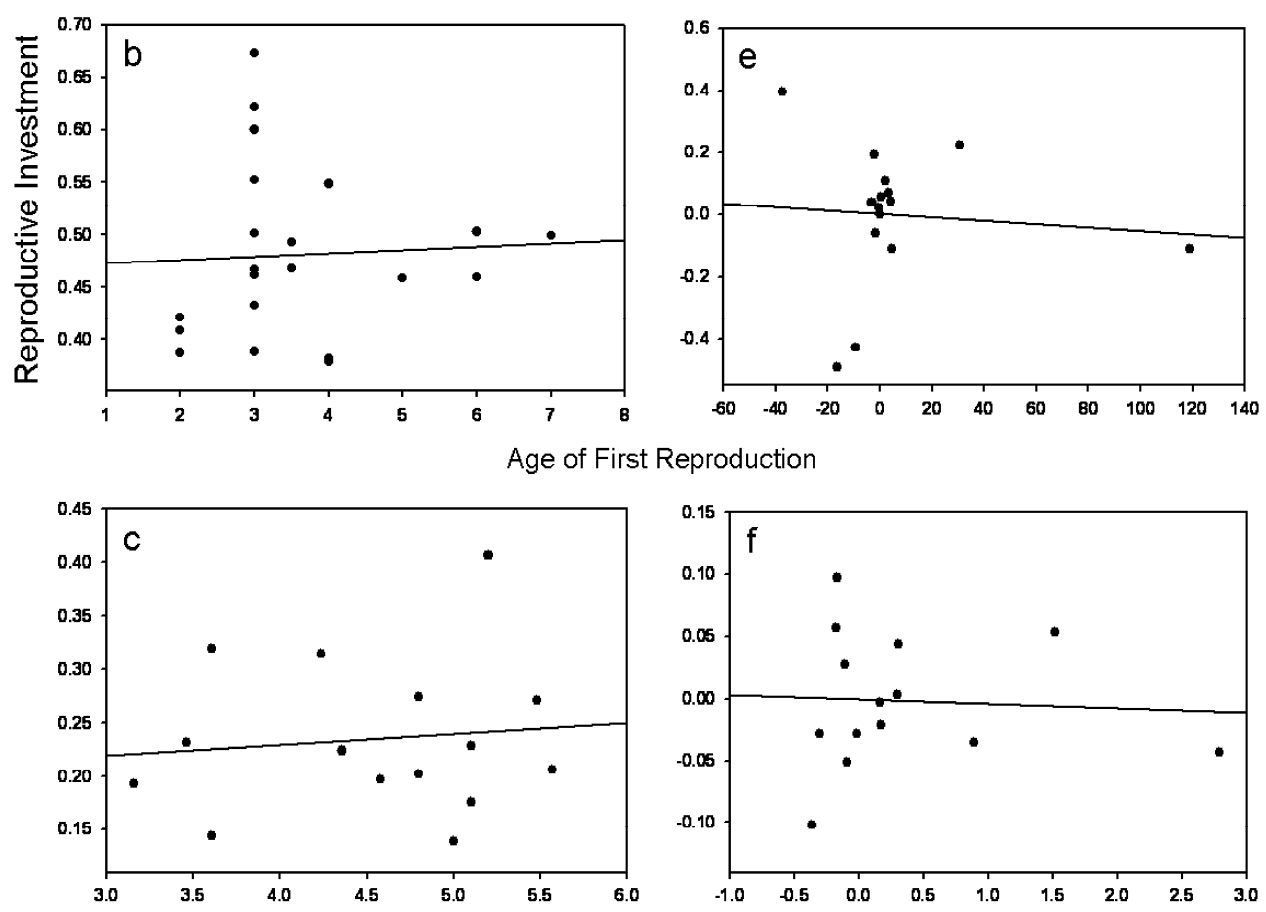

Difference between Longevity Record and Age of First Reproduction

Raw Species

Contrasts

Figure 2-1. Breeding lifespan analyses. In raw species: reproductive investment by (a) adult survivorship, (b) age of first reproduction, and (c) difference between longevity and age of first reproduction. In independent contrasts: reproductive investment by (d) adult survivorship, (e) age of first reproduction, and (f) difference between longevity and age of first reproduction. In all analyses reproductive investment (clutch mass/adult mass) was arcsine square root transformed. In raw species adult survivorship and the difference between longevity and age of first reproduction were log transformed; in contrasts age of first reproduction was log transformed. 


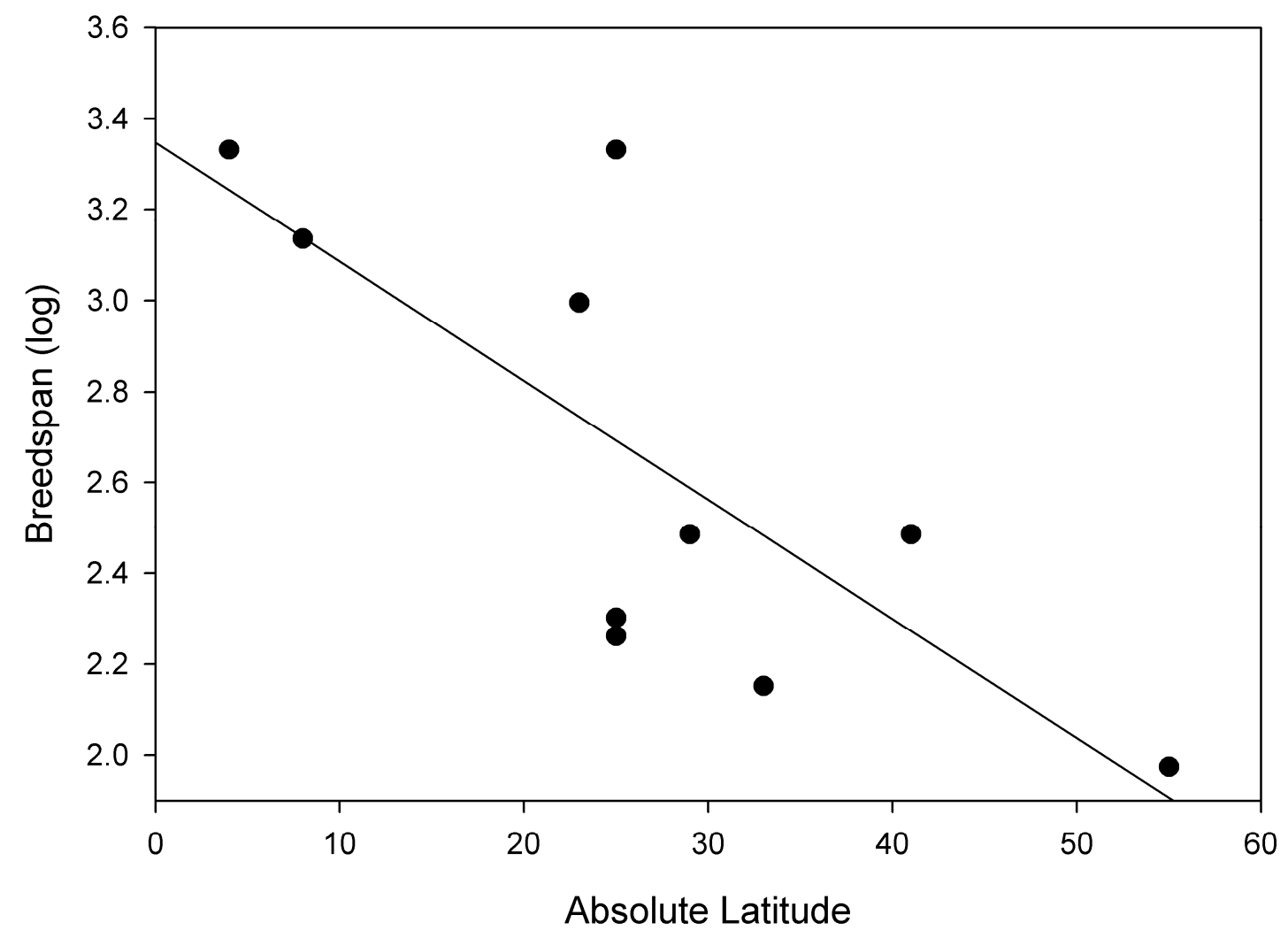

Figure 2-2. Breeding lifespan and latitude. Breeding lifespan, measured as the difference between longevity record and age of first reproduction and log-transformed declines with absolute latitude.

\section{Food Availability}

Reproductive investment increased with food availability in raw species (fig. 2-3a $t_{45}=2.79$, $p=0.004$ ) and after correcting for phylogeny (fig. $2-3 \mathrm{~b} \mathrm{t}_{44}=1.79, p=0.040$ ), and when only hard species were considered (Raw: $\mathrm{t}_{24}=2.76, p=0.006$; Corrected for phylogeny: $\mathrm{t}_{23}=2.02, p=0.028$ ). Latitude did not explain additional variation in investment after considering the role of food availability (fig. 2-4: $\left.\mathrm{t}_{45},=1.18, p=0.123\right)$. 

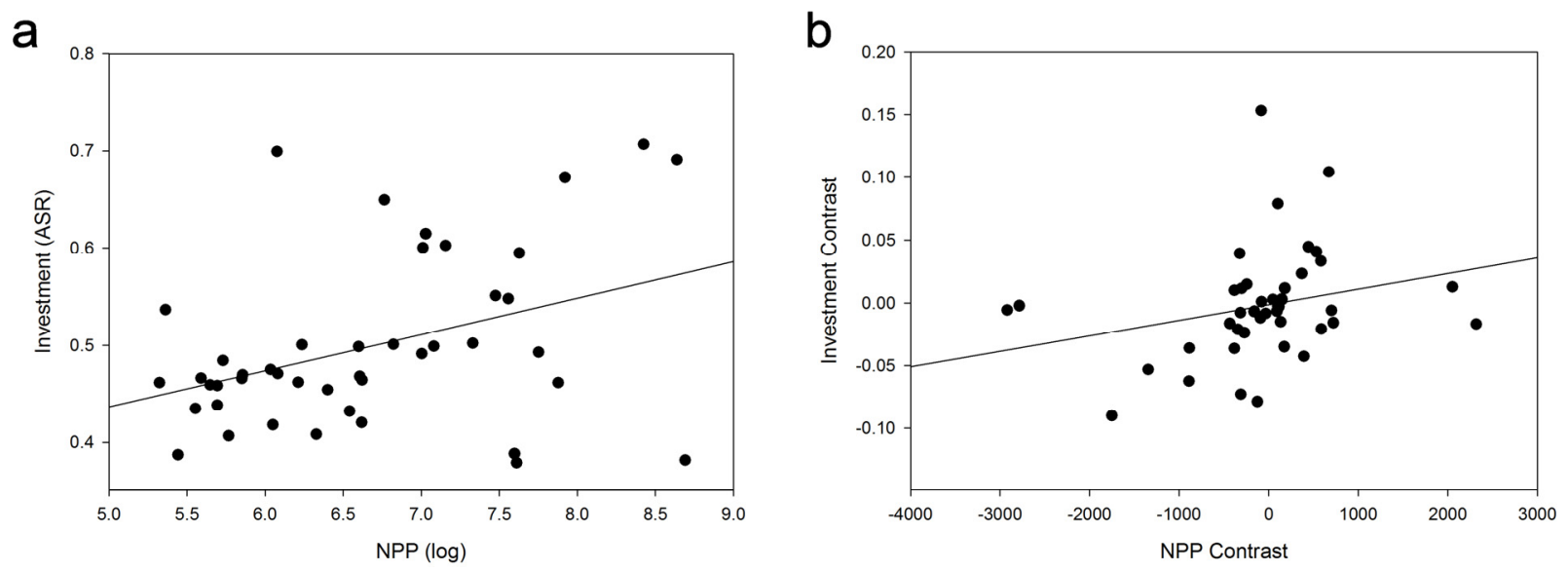

Figure 2-3. Reproductive investment and food availability. (a) Reproductive investment by food availability in raw species. Reproductive investment (clutch mass/adult mass; arcsine square root transformed) increased with food availability (measured as oceanic primary productivity; NPP; log transformed). (b) Reproductive investment by food availability in independent contrasts. After correcting for evolutionary relationships with independent contrasts, there was a positive relationship between food availability (measured by oceanic net primary productivity, NPP) and reproductive investment (clutch mass/adult mass; arcsine square root (ASR) transformed). 


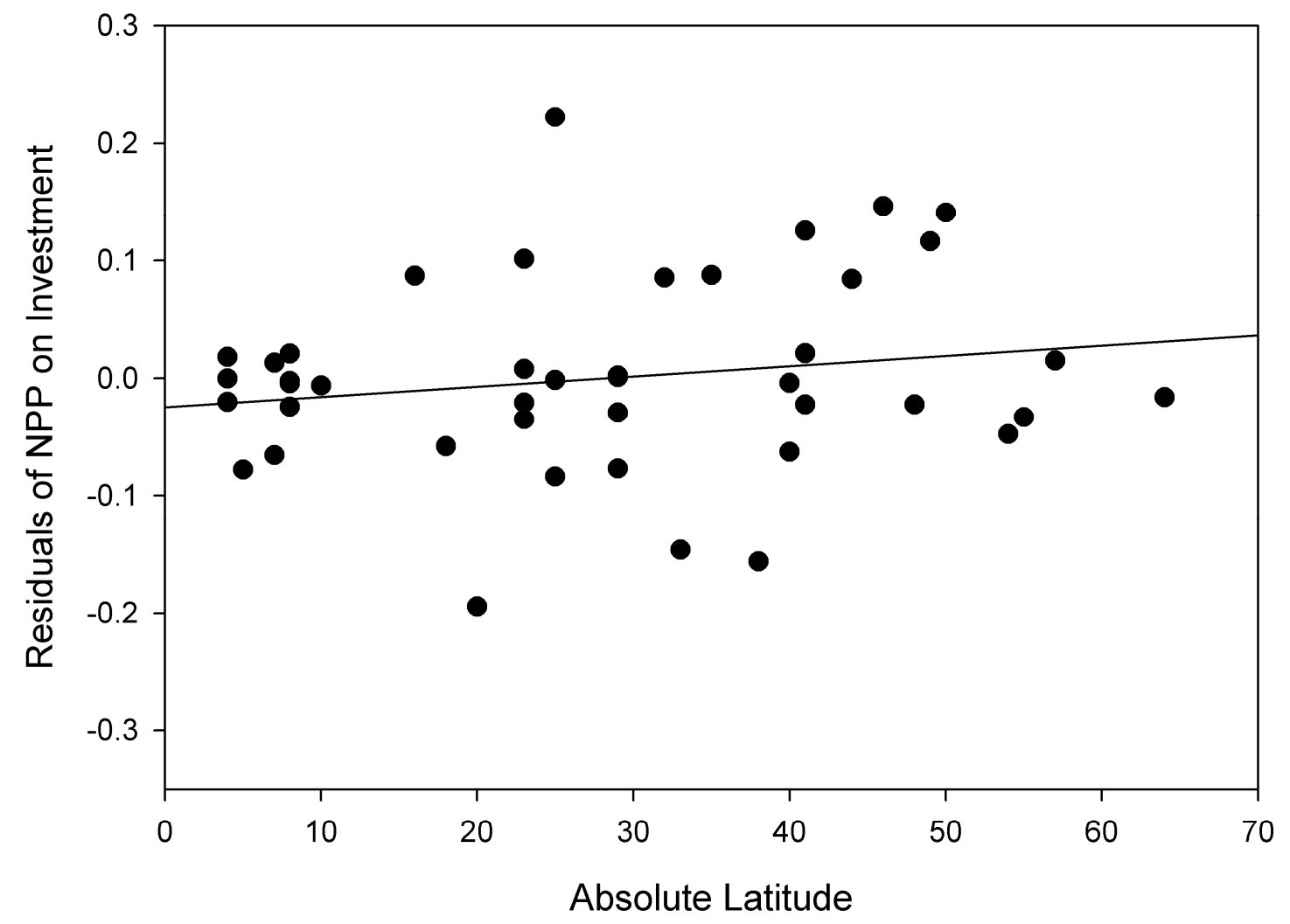

Figure 2-4. Residuals of investment by food availability on absolute latitude. Latitude did not explain additional variation in investment, after considering the role of food availability (measured by oceanic net primary productivity).

\section{Trends within Genera}

The genus Sterna showed a significant positive relationship between food availability and reproductive investment (fig. $2-5 \mathrm{a} \mathrm{t}_{9}=3.16, p=0.016$ ), while non-significant positive trends were found in the genera Anous, Gygis, Onychoprion, and Hydroprogne. Terns in the genus Thalasseus, with the exception of the sandwich tern (Thalasseus sandvicensis), showed a low and constant level of reproductive investment across a wide range of values for food availability (fig. 2-5b). 

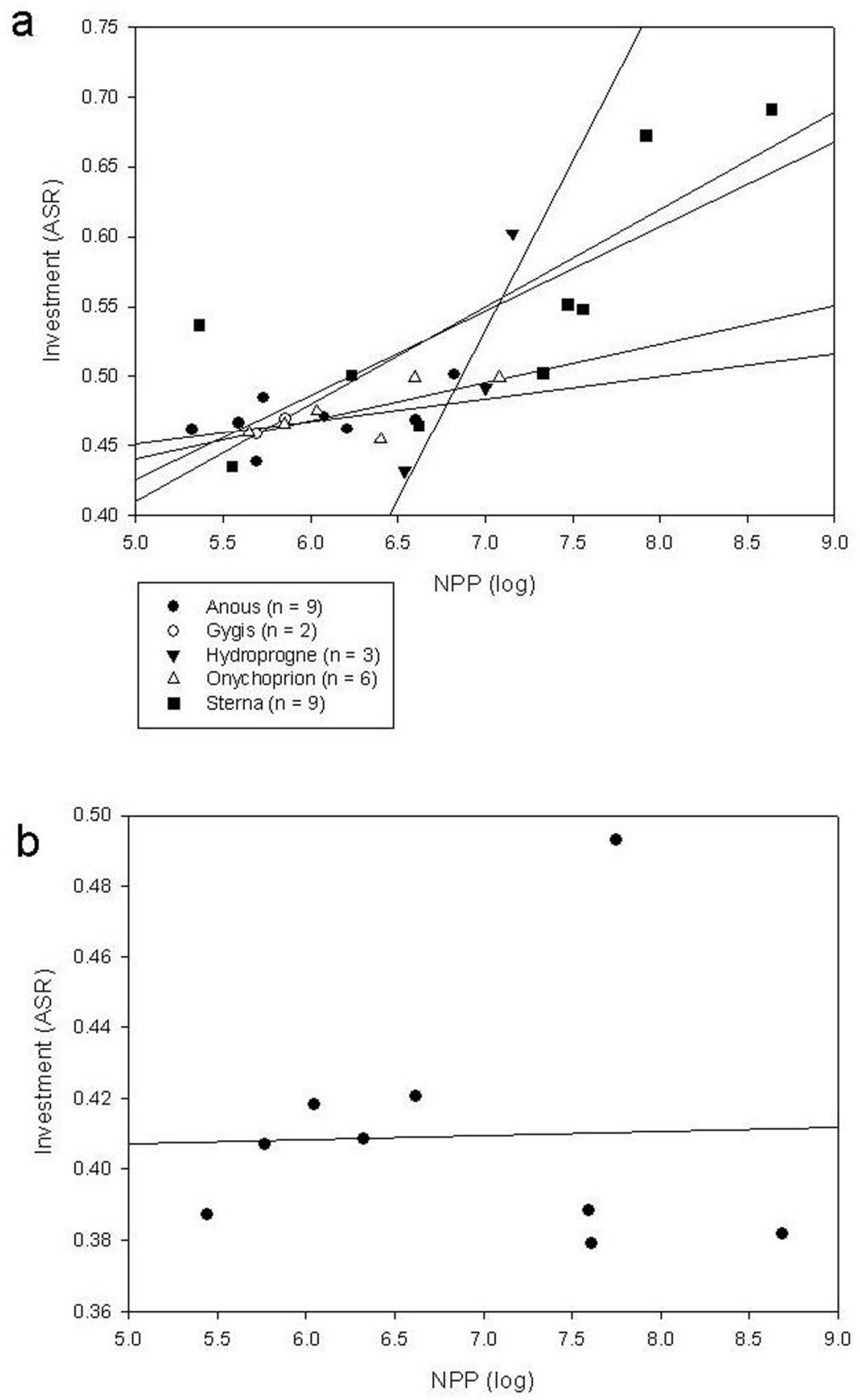

Figure 2-5. Food availability trends within genera. (a) Sterna, Anous, Gygis, Hydroprogne, and Onychoprion showed increasing investment with food availability. (b) Thalasseus terns showed a constant level of investment across food availability. Reproductive investment has been arcsine root transformed (ASR). 


\section{Nest Predation}

Nest predation rate was not related to reproductive investment in raw species $\left(\mathrm{t}_{17}=0.72, \mathrm{p}=0.240\right)$ and after correcting for phylogenetic relationships $\left(\mathrm{t}_{16}=0.66, \mathrm{p}=0.261\right)$. Contrary to the predicted trend, nest predation increased slightly with reproductive investment. Nest predation rate was not correlated with latitude $\left(\mathrm{t}_{17}=0.45, \mathrm{p}=0.330\right)$.
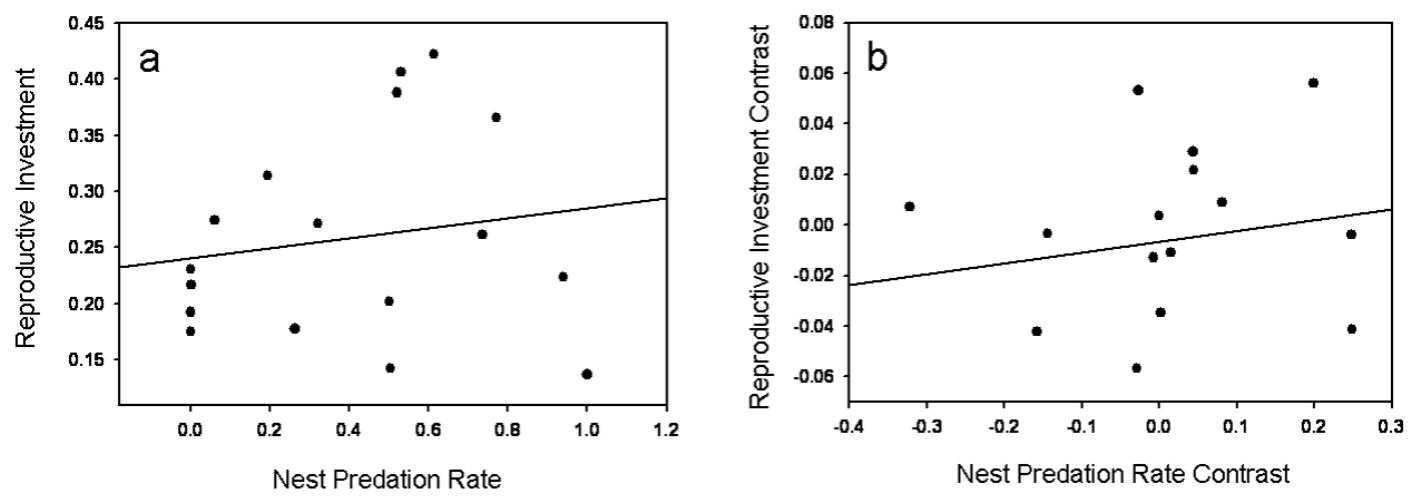

Figure 2-6. Nest predation was not related to reproductive investment in raw species or after correcting for phylogeny.

\section{Conclusion}

\section{Breeding Lifespan}

We were unable to find conclusive evidence to support or reject the breeding lifespan hypothesis, in part, because fewer than 20 records were available for each of the three proxy variables used to evaluate this hypothesis. It is clear that age of first reproduction, which is correlated with breeding lifespan (Roff, 1992), was not related to reproductive investment. Consistent with this finding, roseate terns have been found to have similar adult survival rates across latitude (Nisbet and Ratcliffe, 2008). Many species of terns begin breeding at age 3, and these species showed a wide range of values for reproductive investment (fig. 2-1b), suggesting that breeding lifespan is not related to investment in terns. However, the slight negative relationship between the difference between longevity and age of first reproduction and investment, and the strong negative correlation between this measurement for breeding lifespan and latitude, suggest some support for the breeding lifespan hypothesis. An exploration of this pattern within a population of terns, or with a larger dataset, would shed more light on this potential explanation for the latitudinal gradient in reproductive investment.

\section{Food Availability}

We found support for the hypothesis that food availability is related to reproductive investment in terns, even after correcting for evolutionary relationships (fig. 2-3). Clutch size and fledging rate have been found to correlate with remotely sensed food availability across 8 years in roseate terns, suggesting that terns are able to effectively adjust reproductive output to match food availability (Monticelli and others, 2007). Our analysis does not distinguish an increase in investment because of the ability of parents to raise more young in areas with higher oceanic productivity, as in the original Lack (1954) hypothesis, from an increase because of food limitation preventing female terns, as income breeders, from laying more or larger eggs. Herring gulls (Larus argentatus) have been shown to reduce egg size 
when food availability is low during laying (Kilpi and others, 1996), and equivocal evidence has been found in common terns (Sterna hirundo) in a test of re-laying in response to egg removal (Arnold and others, 1998).

\section{Trends within Genera}

We found increasing reproductive investment with food availability within five tern genera (significant in the Sterna, fig. 2-5a). This pattern suggests that reproductive investment has responded to changes in food availability multiple times as terns evolved. Two Sterna terns have been shown to fledge more young in years of greater food abundance (the common tern and the roseate tern; Safina and others, 1988). The Thalasseus terns, with one exception, show a low and constant level of reproductive investment (fig. 2-5b), suggesting that egg and clutch size are constrained in the larger crested terns. If this branch of terns evolved in a region with low interannual variability in food availability, a constant level of investment might be expected. An examination of interannual variation in food availability and investment would enable an analysis of the pattern in this genus.

\section{Nest Predation}

Nest predation does not appear to drive the latitudinal gradient in reproductive investment among marine-nesting terns. Given terns' lack of dependence on stored resources for reproduction (Moore and others, 2000), their relatively small clutch size, and the slow growth rate of chicks, it has been argued that a parent's ability to forage, rather than nest predation, drives tern reproductive strategies (Langham, 1983). Limited records on predation rates were available, in part, because of variation in the way that predation rate was quantified (eggs or chicks missing, predation events per hour of observation, dissection of predators). Nest predation varies interannually among terns, requiring many data points for a species in a given region to accurately represent nest predation risk. Predation rates are more frequently reported in cases where predators have a large impact on a population and among species at risk. Our analysis is therefore potentially biased by a lack of data on species and populations that experience low levels of nest predation.

Our analysis does not account for other aspects of reproductive investment, including egg quality and quality of parental care, which may be traded off with egg weight or clutch size in tern life history. Roseate and common terns have been found to lay eggs with similar proportions of yolk and albumen, although egg quality in terms of hormonal and lipid content was not considered (Collins and McCroy, 1972).

Tern clutch and egg size in the tropics appear to be constrained by global patterns of food availability. Declines in tropical populations of terns - potentially because of human development, which is more intense in tropical than temperate regions (Population Action International, 2006) - may result in slow and difficult recoveries for these species.

\section{Acknowledgments}

This work is part of a Masters of Science degree at the University of Arizona and committee members Courtney Conway and Bill Shaw provided valuable guidance. Members of the van Riper lab T.J. Fontaine, Tiffany Harvey, Glenn Johnson, Chris O’Brien, and Karla Pelz Serrano provided support and insights. Throughout this work, we collaborated with the conservation and research team of the Intercultural Center for the Study of Deserts and Oceans (CEDO). We are particularly grateful for the contributions of Alejandro Castillo, Hem Nalini Morzaria Luna, and Peggy Turk Boyer. Many thanks 
also to Sandra Fiol, Jess Bloomer, and Heather Green for assistance in the field. We are also grateful to both Georgia Ehlers, in the Graduate College, and Lisa Graumlich, in the School of Natural Resources, for contributions to Alyssa's professional growth, and to Dennis Rosemartin for his support and encouragement.

We would also like to extend our gratitude to Sandra Lanham at E-flying Services for making aerial surveys possible (and safe and enjoyable). Tern researchers Eric Mellink, Eduardo Palacios, Peter Becker, David Monticelli, David Shealer, Charlie Collins, and Ian Nisbet generously shared their thoughts and unpublished data. Robert O'Malley provided invaluable support in accessing and synthesizing remotely-sensed primary productivity data. We are also grateful for the generous financial support of the U.S. Geological Survey, T\&E Incorporated, the PADI Foundation, and the Peace Corps Fellows.

\section{References Cited}

Aebischer, N.J., Coulson, J.C., and Colebrook, J.M., 1990, Parallel long-term trends across four marine trophic levels and weather: Nature, v. 347, p. 753-755.

Alcock, J., 1992, Terns endangered at Estero Morúa: CEDO News, v. 5, p. 9-10.

Arnold, J.M., Nisbet, I.C.T., and Hatch, J. J., 1998, Are Common Terns really indeterminate layers?

Responses to experimental egg removal: Colonial Waterbirds, v. 21, no. 1, p. 81-86.

Atwood, J.L., and Massey, B.W., 1988, Site fidelity of least terns in California: Condor, v. 90, p. 389394.

Behrenfeld, M.J., and Falkowski, P.G., 1997, Photosynthetic rates derived from satellite-based chlorophyll concentration: Limnology and Oceanography, v. 42, p. 1-20.

Boyce, M.S., Kirsch, E.M., and Servheen, C., 2002, Bet-hedging applications for conservation: Journal of Biosciences, v. 27, no. 4, p. 385-392.

Bridge, E.S., Jones, A.W., and Baker, A.J., 2005, A phylogenetic framework for the terns (Sternini) inferred from mtDNA sequences-Implications for taxonomy and plumage evolution: Molecular Phylogenetics and Evolution, v. 35, p. 459-469.

Brusca, R., Cudney-Bueno, R., and Moreno-Báez, M., 2006, Gulf of California esteros and estuariesanalysis, state of knowledge, and conservation and priority recommendations: Final report to the David and Lucille Packard Foundation by the Arizona-Sonora Desert Museum, 60 p.

Burger, J., and Gochfeld, M., 1991, The common tern: New York, Columbia University Press, 413 p.

Calderon-Aguilera, L., Marinone, S., and Aragon-Noriega, E., 2003, Influence of oceanographic processes on the early life stages of the blue shrimp (Litopenaeus stylirorstris) in the upper Gulf of California: Journal of Marine Systems, v. 39, p. 117-128.

Centro de Investigación en Alimentación y Desarrollo, 2006, Red de monitoreo de desarrollos turísticos del noroeste costero: Final Report to the Packard Foundation, $170 \mathrm{p}$.

Collins, C.T., and LeCroy, M., 1972, Analysis of measurements, weights and composition of common and roseate tern eggs: The Wilson Bulletin, v. 8, n. 2, p. 187-192.

Diario Oficial de la Federación, 2000, NOM-ECOL-059-2000. Protección ambiental-Especies de flora y fauna silvestres de México-Categorías de riesgo y especificaciones para su inclusión, exclusión o cambio-Lista de especies en riesgo, $54 \mathrm{p}$.

Diario Oficial de la Federación, 2007, Ley General de Equilibrio Ecológico y Protección al. Ambiente, $64 \mathrm{p}$.

Ekman, J., and Askenmo, V., 1986, Reproductive cost, age-specific survival and a comparison of the reproductive strategy in two European tits (genus Parus): Evolution, v. 40, no. 1, p. 159-168. 
Faaborg, J., and Arendt, W. J., 1995, Survival rates of Puerto Rican birds - are islands really that different?: The Auk, v. 112, no. 2, p. 503-507.

Food and Agriculture Organization of the United Nations, 2007, The world's mangroves 1980-2005: Rome, Food and Agriculture Organization of the United Nations, FAO Forestry Paper 153, 89 p.

Fontaine, J.J., and Martin, T.E., 2006, Parent birds assess nest predation risk and adjust their reproductive strategies: Ecology Letters, v. 9, no. 4, p. 428-434.

Fox, C.W., and Czesak, M.E., 2000, Evolutionary ecology of progeny size in arthropods: Annual Review of Entomology, v. 45, p. 341-369.

Garland, T. Harvey, P.H., and Ives, A.R., 1992, Procedures for the analysis of comparative data using phylogenetically independent contrasts: Systematic Biology, v. 41, no. 1, p. 18-32.

Gill, R.E., 2008, Caspian terns nesting in Alaska-prophecy, serendipity, and implications for regional climate-related change: Western Birds, v. 39, p. 97-100.

Glenn, E.P., Nagler, P., Brusca, R.C., and Hinojosa-Huerta, O., 2006, Coastal wetlands of the northern Gulf of California - inventory and conservation status: Aquatic Conservation-Marine and Freshwater Ecosystems, v. 16, p. 15-28.

Gochfeld, M., 1983, Colony site selection by least terns - physical attributes of sites: Colonial Waterbirds, v. 6, p. 205-213.

Gonzalez, G.R., Esq., and Gastelum, M.E., 1999, Overview of the environmental laws of Mexico: San Diego, Calif., Haight, Brown \& Bonesteel, LLP., accessed April 2, 2009, at http://www.natlaw.com/pubs/spmxen13.htm.

Hamer, K.C., Schreiber, E.A., and Burger, J., 2001, Breeding biology, life histories, and life historyenvironment interactions in seabirds, in Schreiber, E.A., and Burger, J., eds., Tropical seabird biology: Lawrence, Kans., Allen Press, p. 217-261.

Hemborg, C., Sanz, J.J., and Lundberg, A., 2001, Effects of latitude on the trade-off between reproduction and moult: a long-term study with pied flycatcher: Oecologia, v. 129, p. 206-212.

Hinrichsen, D., 1998, Coastal waters of the world - trends, threats, and strategies: Washington, D.C., Island Press, $298 \mathrm{p}$.

Hockey, P.A.R., and Wilson, W.A., 2003, Reproductive traits of marine terns (Sternidae) —evidence for food limitation in the tropics?: Ostrich, v. 74, p. 110-116.

Instituto Nacional de Estadística y Geografía, 2005, Population estimates, foreign-born residents, growth by city: Instituto Nacional de Estadística y Geografía database, accessed May 12, 2010, at http://www.inegi.gob.mx.

Intercultural Center for the Study of Deserts and Oceans, 2007, Diagnóstico Social y Ambiental para la Aplicación de Herramientas Legales de Conservación en Tierras Privadas y Sociales en torno a Tres Esteros del Golfo Norte de California, Sonora: Final Report to Fondo Mexiano para la Conservación de la Naturaleza 1-110.

Intergovernmental Panel on Climate Change, 2007, Climate change 2007-the physical basissummary for policymakers, accessed May 23, 2007, at http://www.ipcc.ch/pdf/assessment-report/ar4/wg1/ar4-wg1-spm.pdf

JMP IN, Version 5.1: Cary, N.C., SAS Institute Inc., www.jmp.com.

Kastelein, B., 2003, Mexican ministry wraps up evaluation of Baja project, approves master plan: International Environment Reporter, v. 26, no. 6, p. 1148.

Kilpi, M., Hillstrom, L., and Lindstrom, K., 1996, Egg-size variation and reproductive success in the Herring Gull Larus argentatus — adaptive or constrained size of the last egg?: Ibis, v. 138, no. 2, p. 212-217. 
Klimkiewicz, M.K., 2008, Longevity records of North American birds, Version 2008.1: Laurel, Md., U.S. Geological Survey database, Patuxent Wildlife Research Center, Bird Banding Laboratory, accessed May 12, 2010, at http://www.pwrc.usgs.gov/BBL/homepage/longvrec.htm.

Kotliar, N.B., and Burger, J., 1986, Colony site selection and abandonment by least terns (Sterna antillarum) in New Jersey, U.S.A: Biological Conservation, v. 37, p. 1-21.

Lack, D., 1954, The evolution of reproductive rates, in Silver, R., ed., Parental behavior in birds: Stroudsburg, Pa., Dowden, Hutchinson \& Ross Inc., 435 p.

Langham, N.P., 1983, Growth strategies in marine terns: Studies in Avian Biology, v. 8, p. 73-83.

Lavín, M.F., Godínez, V.M., and Alvarez, L.G., 1998, Inverse-estuarine features of the upper Gulf of California: Estuarine, Coastal and Shelf Science, v. 47, p. 769-795.

Maddison, W.P., and Maddison, D.R., 2004, Mesquite - a modular system for evolutionary analysis, Version 1.05, accessed May 12, 2010, at http://mesquiteproject.org.

Martin, T.E., Bassar, R.D, Basser, S.K., Fontaine, J.J., Lloyd, P., Mathewson, H.A., Niklison, A.M., and Chalfoun, A., 2006, Life-history and ecological correlates of geographic variation in egg and clutch mass among passerine species: Evolution, v. 60, no. 2, p. 390-398.

Massey, B., 1974, Breeding biology of the California least tern: Proceedings of the Linnaean Society of New York, v. 72, p. 1-24.

Massey, B., and Fancher, J.W., 1989, Re-nesting by California least terns: Journal of Field Ornithology, v. 60 , p. $350-357$.

Mazzocchi, A.B., and Forys, E.A., 2005, Nesting habitat selection of the least tern on the gulf coast of Florida: Florida Field Naturalist, v. 33, no. 3, p. 71-80.

Mellink, E., and Palacios, E., 1993, Notes on breeding coastal waterbirds in northwestern Sonora: Western Birds, v. 24, p. 29-37.

Midford, P.E., Garland, T., Jr., and Maddison, W.P., 2005, PDAP Package of Mesquite, Version 1.07, accessed May 12, 2010, at http://mesquiteproject.org/pdap_mesquite/index.html.

Monaghan, P., Uttley, J.D., Burns, M.D., Thaine, C., and Blackwood, J., 1989, The relationship between food supply, reproductive effort and breeding success in arctic terns (Sterna paradisaea): The Journal of Animal Ecology, v. 58, no. 1, p. 261-274.

Monticelli, D., Ramos, J.A., and Quartly, G.D., 2007, Effects of annual changes in primary productivity and ocean indices on the breeding performance of tropical roseate terns in the western Indian Ocean: Marine Ecology Progress Series, v. 351, p. 273-286.

Moore, D.J., Williams, T.D., and Morris, R.D., 2000, Mate provisioning, nutritional requirements for egg production, and primary reproductive effort of female common terns Sterna hirundo: Journal of Avian Biology, v. 31, p. 183-196.

Nelson, B., 1980, Seabirds - their biology and ecology: London, The Hamlyn Publishing Group Limited, $224 \mathrm{p}$.

Nelson, J.B., 1983, Contrasts in breeding strategies between some tropical and temperate marine Pelecaniformes: Studies in Avian Biology, v. 8, p. 95-114.

Nisbet, I.C.T, and Ratcliffe, N., 2008, Comparative demographics of tropical and temperate roseate terns: Waterbirds, v. 31, no. 3, p. 346-356.

Oregon State University, 2008, Ocean productivity: Oregon State University database, accessed May 12, 2010, http://www.science.oregonstate.edu/ocean.productivity/index.php.

Palacios, E., and Mellink, E., 1996, Status of the least tern in the Gulf of California: Journal of Field Ornithology, v. 67, p. 48-58.

Population Action International, 2006, Population International online maps, accessed May 12, 2010, at www.populationaction.org/mappingthefuture. 
Rahmstorf, S., 2007, A semi-empirical approach to projecting future sea-level rise: Science, v. 315, p. 368-370.

Rahn, H., Paganelli, C.V., Nisbet, I.C.T., and Whittow, G.C., 1976, Regulation of incubation water-loss in eggs of seven species of terns: Physiological Zoology, v. 49, p. 249-259.

Ricklefs, R.E., 1983, Some considerations on the reproductive energetics of pelagic seabirds: Studies in Avian Biology, v. 8, p. 84-94.

Roberts, C.M., McClean, C.J., Veron, J.E.N., Hawkins, J.P., Allen, G.R., McAllister, D.E., Mittermeier, C.G., Schueler, F.W., Spalding, M., Wells, F., Vynne, C., and Werner, T.B., 2002, Marine biodiversity hotspots and conservation priorities for tropical reefs: Science, v. 295, no. 5558, p. 12801284.

Roff, D.A., 1992, The evolution of life histories - theory and analysis: New York, Chapman and Hall, $535 \mathrm{p}$.

Russell, S.M., and Monson, G., 1998, The birds of Sonora: Tucson, Ariz., University of Arizona Press, $360 \mathrm{p}$.

Safina, C., Burger, J., and Wagner, R.H., 1988, Evidence for prey limitation of common and roseate tern reproduction: The Condor, v. 90, p. 852-859.

Schonwetter, M., 1960, Handbuch der Oologie, vol. 1, W. Meise, ed.: Berlin, Akademie Verlag.

Shwiff, S.A., Sterner, R.T., Turman, J.W., and Foster, B.D., 2005, Ex post economic analysis of reproduction-monitoring and predator-removal variables associated with protection of the endangered California least tern: Ecological Economics, v. 53, no. 2, p. 277-287.

Simpson, R.L., Good, R.E., Leck, M.A., and Whigham, D.F., 1983, The ecology of freshwater tidal wetlands: BioScience, v. 33, no. 4, p. 255-259.

Skutch, A.F., 1949, Do tropical birds rear as many young as they can nourish?: Ibis, v. 91, p. 430-458.

Slagsvold, T., 1982, Clutch size variation in passerine birds - the nest predation hypothesis: Oecologia, v. 54, p. 159-169.

Solis, J.G., Wendeln, H., and Becker, P.H., 1999, Within and between season nest site and mate fidelity in Common Terns (Sterna hirundo): Journal fur Ornithologie, v. 140, p. 491-498.

Spendelow, J.A., Nichols, J.D., Nisbet, I.C.T., Hays, H., Cormons, G.D., Burger, J., Safina, C., Hines, J.E., and Gochfeld, M., 1995, Estimating annual survival and movement rates of adults within a metapopulation of roseate terns: Ecology, v. 76, p. 2415-2428.

Stearns, S.C., 1992, The evolution of life histories: Oxford, N.Y., Oxford University Press, 248 p.

Steinkamp, M., Peterjohn, J.E., Byrd, V., Carter, H., and Lowe, R., 2003, Breeding season survey techniques for seabirds and colonial waterbirds throughout North America, 81 p., accessed May 12, 2010, at http://www.pwrc.usgs.gov/cwb/manual/.

Stonehouse, B., 1963, Egg dimensions of some Ascension Island seabirds: Ibis, v. 103b, p. 474-482.

Suddaby, D., and Ratcliffe, N., 1997, The effects of fluctuating food availability on breeding arctic terns (Sterna paradisaea): The Auk, v. 114, no.3, p. 524-530.

Thompson, B.C., Jackson, J.A., Burger, J., Hill, L.A., Kirsch, E.M., and Atwood, J.L., 1997, Least tern (Sternula antillarum), Issue no. 290, in Poole, A., ed., The birds of North America online: Ithaca, Cornell Lab of Ornithology, accessed May 12, 2010, at http://bna.birds.cornell.edu/bna/species/290/articles/introduction.

Thompson, B.C., and Slack, R.D., 1982, Physical aspects of colony site selection by least terns on the Texas Coast: Colonial Waterbirds, v. 5, p. 161-168.

Thompson, G.D., and Wilson, P.N., 1994, Ejido reforms in Mexico-conceptual issues and potential outcomes: Land Economics, v. 70, no. 4, p. 448-465. 
Thurman, H.V., 1997, Introductory oceanography, ( $8^{\text {th }}$ ed.): Upper Saddle River, N.J., Prentice-Hall, $544 \mathrm{p}$.

U.S. Census Bureau, 2008, State and County QuickFacts, population estimates, Tucson: U.S. Census Bureau database, accessed May 12, 2010, at http://quickfacts.census.gov/qfd/states/04/0477000.html.

U.S. Fish and Wildlife Service, 2006, California least tern (Sternula antillarum browni) 5-year reviewsummary and evaluation: Carlsbad, Calif., U.S. Fish and Wildlife Service, Carlsbad Fish and Wildlife Office, $32 \mathrm{p}$.

U.S. Fish and Wildlife Service, 1985, Revised California least tern recovery plan, 107 p.

U.S. Geological Survey, 1997, Colonial waterbird inventory and monitoring program: U.S. Geological Survey database, Patuxent Wildlife Research Center, accessed May 13, 2010, http://idn.ceos.org/portals/Metadata.do?Portal=ceos\&KeywordPath=[Keyword\%3D\%27OHIO\%27]\& OrigMetadataNode $=$ GCMD\&EntryId $=$ BRDPWRC0008\&MetadataView $=$ Full\&MetadataType $=0 \& l b$ node $=$ mdlb2.

Weimerskirch, H., 2001, Seabird demography and its relationship with the marine environment, in Schreiber, E.A., and Burger, J., eds., Tropical seabird biology: Lawrence, Kans., Allen Press, p. 115136.

Zedler, J.B., 1996, Coastal mitigation in southern California-the need for a regional restoration strategy: Ecological Applications, v. 6, p. 84-93.

Zuria, I., and Mellink, E., 2002, Natural and human impacts on two least tern colonies in northwestern Mexico: Southwestern Naturalist, v. 47, p. 617-622.

Zuria, I., and Mellink, E., 2005, Fish abundance and the 1995 nesting season of the least tern at Bahía San Jorge, Northern Gulf of California, Mexico: Waterbirds, v. 28, p. 172-180. 


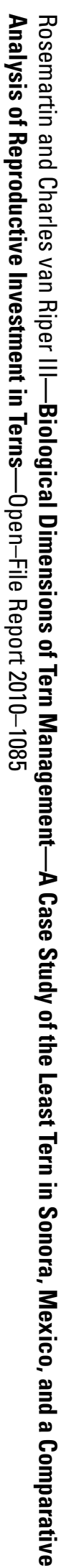

